\title{
Recent Advances on Edible Films Based on Fruits and Vegetables-A Review
}

\author{
Caio G. Otoni, Roberto J. Avena-Bustillos iD, Henriette M. C. Azeredo, Marcos V. Lorevice, Márcia R. Moura, \\ Luiz H. C. Mattoso iD, and Tara H. McHugh
}

\begin{abstract}
Food packaging materials are traditionally expected to contain foodstuffs and protect them from deteriorating agents. Although petroleum-derived polymers have been widely used for this purpose, the rising concern with their nonrenewable and/or nonbiodegradable nature paves the route for the development of greener alternatives, including polysaccharides and polypeptides. The use of these food-grade biomacromolecules, in addition to fruits and vegetables, provides edible packaging with suitable physical-mechanical properties as well as unique sensory and nutritional characteristics. This text reviews the chronological development pathway of films based on fruit and vegetable purees, pomaces, and extracts. Recent advances are extensively reviewed with an emphasis on the role that each film component plays in the resulting materials, whose production methods are examined from a technical standpoint and essential properties are compiled and contrasted to their conventional, synthetic counterparts. Finally, this comprehensive review discusses advantages and limitations of edible films based on fruits and vegetables.
\end{abstract}

Keywords: active packaging, biodegradable material, biopolymer, food packaging, multifunctional film

\section{Introduction}

Food packaging systems have different functions, including those related to containment, information, and marketing. Their primary function, though, is to separate food from the surrounding environment, reducing exposure to spoilage factors (for example, microorganisms, oxygen, water vapor, and off-flavors) and avoiding losses of desirable compounds (such as flavor volatiles), thus extending food shelf-life.

Natural polymeric materials such as cotton, wood, silk, wool, and leather have been used for centuries, and their structural and functional properties have influenced the development of petroleum-based polymers. Those plastics markedly increased in popularity throughout the 2 nd half of the 20th century, until they dominated the food packaging market, thanks to their relatively low price, mechanical resistance, heat sealability, shape versatility, and degrees of rigidity. However, those fossil fuels are nonrenew-

CRF3-2017-0014 Submitted 1/17/2017, Accepted 5/25/2017. Authors Otoni, Lorevice, and Mattoso are with Natl. Nanotechnology Laboratory for Agribusiness, Embrapa Instrumentação-Rua XV de Novembro, 1452, São Carlos, SP 13560-979, Brazil. Authors Otoni and Mattoso are with PPG-CEM, Dept. of Materials Engineering, Federal Univ. of São Carlos-Rod. Washington Luis, km 235, São Carlos, SP 13565-905, Brazil. Authors Avena-Bustillos and McHugh are with Healthy Processed Foods Research, Western Regional Research Center, Agricultural Research Service, USDA-800 Buchanan St., Albany, CA, 94710, USA. Author Azeredo is with Embrapa Tropical Agroindustry-Rua Dra Sara Mesquita, 2270, Fortaleza, CE 60511-110, Brazil. Author Lorevice is with PPGQ, Dept. of Chemistry, Federal Univ. of São Carlos-Rod. Washington Luis, km 235, São Carlos, SP 13565-905, Brazil. Author Moura is with Dept. of Physics and Chemistry, FEIS, São Paulo State Univ-Av. Brasil, 56, Ilha Solteira, SP 15385-000, Brazil. Direct inquiries to authors Mattoso and Otoni (E-mail:1 luiz.mattoso@embrapa.br, cgotoni@gmail.com). able and mostly nonbiodegradable. Only in the United States, more than 32 million tons of plastics are discarded yearly (EPA 2016). Recycling is limited because of technical and economic difficulties; actually, less than $3 \%$ of the waste plastic worldwide gets recycled (HKC 2016). Moreover, their incineration can produce toxic compounds, such as furans and dioxins produced from burning polyvinylchloride (PVC) (Jayasekara and others 2005). The accumulated waste generated by the continuous, extensive disposal of petroleum-derived polymers has raised considerable concerns over their deleterious effects on the environment.

In this context, there has been a worldwide demand for replacing conventional plastics by renewable and biodegradable polymers in the last decades (Babu and others 2013). Bio-based polymers - that is, from renewable rather than fossil sources-are not necessarily biodegradable. Polyethylene (PE) and polypropylene (PP) are possibly renewable, since their monomers can be derived from ethanol - but that does not make bio-PE and bio-PP any more biodegradable than their petroleum-based counterparts. Also, biodegradable polymers can be either bio-based, like starch, or petroleum-derived, poly ( $\varepsilon$-caprolactone) (PCL), for instance.

Ideal candidates for replacing conventional polymers should be both renewable and biodegradable. Polysaccharides and polypeptides address those requirements and have good film-forming properties. Most proteins and carbohydrates are also edible, and can be used as matrices for edible films and coatings, which are supposed to be ingested with the food (Krochta 2002). On the other hand, biodegradable materials are not necessarily edible. Edible films should have only food-grade components in their compositionsincluding not only the film-forming matrix and the solvent, but also plasticizers and any other additives. 


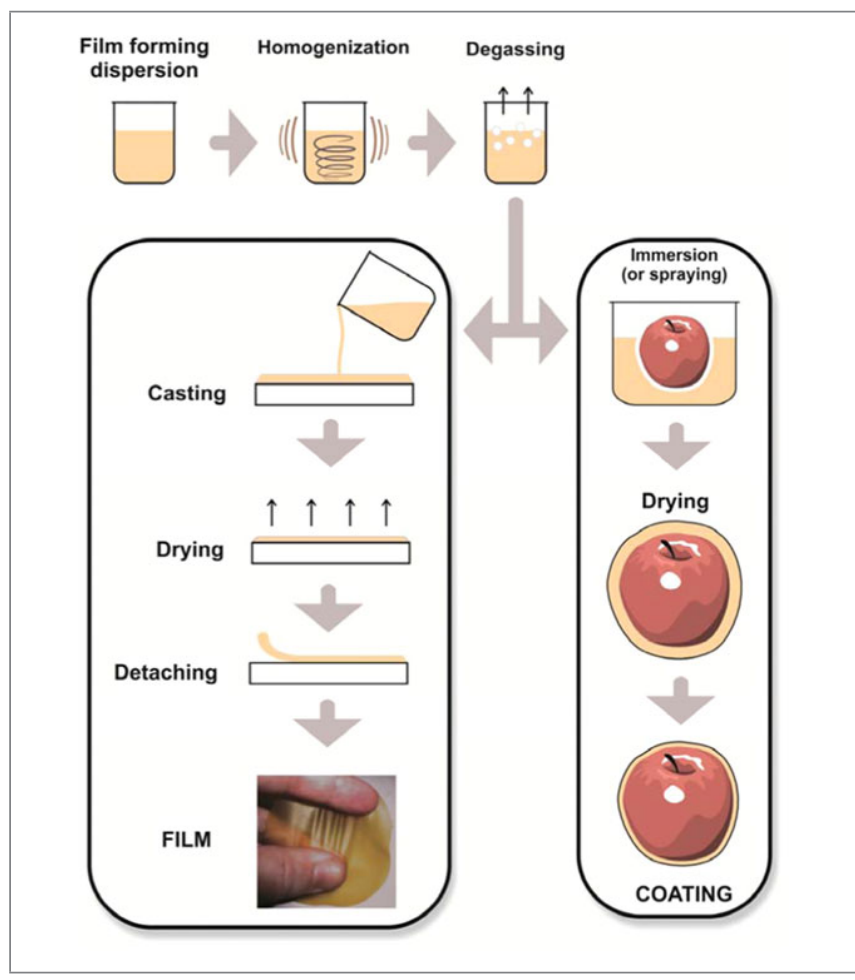

Figure 1-Schematic representation of production of films and coatings.

Edible films and coatings are sometimes presented as synonymous, but they are applied differently (Figure 1).

Basically, films are stand-alone structures preformed separately and then applied on food surface, between food components, or even sealed into edible pouches. Edible coatings, in turn, are formed directly onto food surface by dipping, spraying or panning, the latter being achieved by mixing both the food material and the coating solution in a rotating bowl followed by drying (Krochta and De Mulder-Johnston 1997; Andrade and others 2012). Although edible films and coatings are not expected to completely replace conventional packaging materials, they can be used to extend food stability by reducing exchange of moisture, gasses, lipid, and volatiles between the food and the surrounding environment and by preventing surface contamination, helping to improve efficiency of food packaging, and thus reducing requirements for petroleum-derived polymers (Krochta and De Mulder-Johnston 1997).

The barrier requirements of edible films and coatings depend on their application and the properties of the food that is to be protected. Films or coatings for fresh fruits and vegetables should have low water vapor permeability (WVP) in order to reduce desiccation rates, while oxygen permeability $\left(\mathrm{O}_{2} \mathrm{P}\right)$ should be low enough to retard respiration, but not too low to create anaerobic conditions favorable to ethanol production and off-flavor formation (Lin and Zhao 2007). Films or coatings for nuts, as another example, should have low $\mathrm{O}_{2} \mathrm{P}$ in order to reduce lipid oxidation rates, and low WVP to reduce water absorption and loss of crunchy texture.

Edible films and coatings should have at least 2 components: a biomacromolecule-based matrix able to form a cohesive structure and a solvent (usually water). A plasticizer is often required for reducing brittleness inherent to most biopolymers. Some other components, such as crosslinkers and nanoreinforcements, can

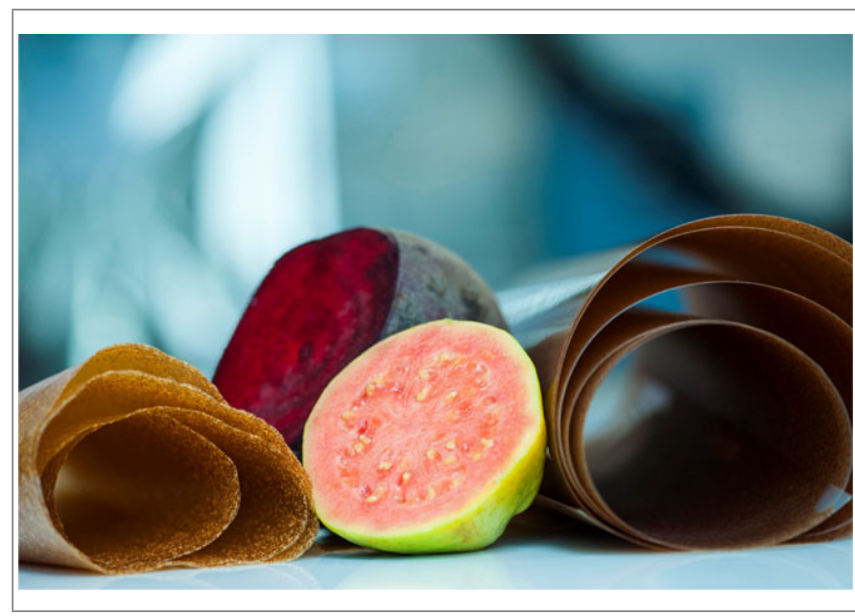

Figure 2-Edible films made up of guava (left) and beetroot (right) purees produced at Embrapa Instrumentação, Brazil.

be incorporated to improve barrier, tensile, and water resistance properties.

Usually, edible films and coatings are supposed to be transparent and flavorless, not interfering with food sensory properties. However, specific sensory properties may be desirable for some applications, such as sushi wraps, pouches to be melted on cooking, films between crust and toppings of pizzas, or even film snacks. In this context, McHugh and others (1996) produced the 1st edible films based on fruit purees (McHugh and others 2006, 2012). Since then, several studies have been carried out on the development of films made up of fruits and vegetables. These investigations rely upon combining film-forming hydrocolloids (including starch, pectin, cellulose, and hemicellulose) with fruit and vegetable purees (Azeredo and others 2009). Moreover, fruit and vegetable are sources of nutrients and antioxidants that may be ingested in form of edible films made from them (Deng and Zhao 2011; Espitia and others 2014). Figure 2 presents edible films based on guava and beetroot purees. Advantages of edible films over fresh produce include improved shelf life, lower cost (due to the possibility of using mechanically harvested plants), and year-round processing (McHugh and others 1996).

The consumption of fruits and vegetables is getting more popular because of their health benefits, so that edible films based on these plant materials denote an alternative means of nutrient intake (Espitia and others 2014), including pigments and polyphenols with antioxidant capacity (Deng and Zhao 2011).

This text reviews the chronological development pathway of films based on fruit and vegetable purees, pomaces, and extracts, from the very pioneer study of McHugh and others (1996) up to the products currently available commercially. Recent advances on composite and active edible films based on fruits and vegetables are extensively reviewed, in addition to the role of each film component, as well as the production protocols. Finally, advantages and limitations of those materials are weighed and the upcoming scenario is discussed.

\section{Basic Concepts/Fundamentals}

Films based on fruits and vegetables may be produced from a single macromolecule type, blends or even composites/multi component (comprising macromolecules, fillers, and/or functional additives). They may be produced as single- or multi-layer materials in order to achieve the target performance. Regardless 
Fruit and vegetable edible films...

Table 1-Purees, pomaces, extracts/juices of fruits and vegetables used for edible film production.

\begin{tabular}{|c|c|c|c|c|}
\hline \multirow[b]{2}{*}{ Common name } & \multirow[b]{2}{*}{ Scientific name } & \multicolumn{3}{|c|}{ References } \\
\hline & & Puree & Pomace & Extract/juice \\
\hline Açaí & Euterpe oleracea Mart. & $1-2$ & & \\
\hline Apple & Malus domestica Borkh., M. pumila Mill., Pyrus malus L. & $3-13$ & 14 & \\
\hline Apricot & Prunus armeniaca $\mathrm{L}$. & 3 & & \\
\hline Banana & Musa $\times$ paradisiaca L., M. cavendishii Lamb. & $15-17$ & 18 & \\
\hline Barbados cherry (acerola) & Malpighia emarginata DC., M. glabra L., M. punicifolia L. & $19-25$ & & 26 \\
\hline Broccoli & Brassica oleracea & 13 & & \\
\hline Carrot & Daucus carota L. & $4-5,13,27-28$ & 29 & \\
\hline Cashew apple & Anacardium occidentale L. & & & 26 \\
\hline Celery & Apium graveolens $\mathrm{L}$. & 30 & & \\
\hline Corn & Zea mays L. & & & $31-32$ \\
\hline Courgette & Cucurbita pepo L. & & 29 & \\
\hline Cranberry & Vaccinium macrocarpon Aiton & & 33 & \\
\hline Cucumber & Cucumis sativus $\mathrm{L}$. & & 17 & \\
\hline Fennel & Foeniculum vulgare Mill. & & 34 & \\
\hline Gooseberry & Riber uva-crispa L. & 35 & & \\
\hline Grape & Vitis vinifera $\mathrm{L}$. & & $36-37,54$ & \\
\hline Guava & Psidium guajava $\mathrm{L}$. & $38-39$ & & \\
\hline Hibiscus & Hibiscus sabdariffa L. & $4-5$ & & \\
\hline Lettuce & Lactuca sativa $\mathrm{L}$. & & 29 & \\
\hline Mango & Mangifera indica $\mathrm{L}$. & $19,23-25,40-43$ & & \\
\hline Mint & Mentha sp & & 29 & \\
\hline Orange & Citrus sinensis (L.) Osbeck & & 29 & \\
\hline Papaya & Carica papaya L. & $44-46$ & & 26 \\
\hline Passion fruit & Passiflora edulis Sims. & 39 & 29 & \\
\hline Peach & Prunus persica (L.) Batsch & $3,13,47$ & & \\
\hline Pear & Pyrus communis $\mathrm{L}$. & 3,48 & & \\
\hline Pequi & Caryocar brasiliense Cambess. & & & 26 \\
\hline Pomegranate & Punica granatum $\mathrm{L}$. & & & 26 \\
\hline Red mombin & Spondias purpurea $\mathrm{L}$. & 19 & & \\
\hline Rocket & Eruca sativa Mill. & & 29 & \\
\hline Spinach & Spinacea oleracea L. & & 29,37 & \\
\hline Strawberry & Fragaria $\times$ ananassa Duch., $F$. vesca $\mathrm{L}$. & 50 & & 26 \\
\hline Taro & Colocasia esculenta (L.) Schott & & 29 & \\
\hline Tomato & Solanum lycopersicum L. & $11,51-53$ & & \\
\hline Watermelon & Citrullus lanatus (Thunb.) & 39 & 29 & \\
\hline Yerba mate & Ilex paraguariensis A. St.-Hil. & & & 24 \\
\hline
\end{tabular}

Cited literature: ${ }^{1}$ Espitia and others (2014a); ${ }^{2}$ Espitia and others (2014b); ${ }^{3}$ McHugh and others Krochta (1996); ${ }^{4}$ Ravishankar and others (2012); ${ }^{5}$ Zhu and others (2014); ${ }^{6}$ McHugh and Senesi (2000); ${ }^{7}$ Rojas-Graü and others (2006); ${ }^{8}$ Du and others (2008b); ${ }^{9}$ Du and others (2009a); ${ }^{10}$ Du and others (2011); ${ }^{11}$ Du and others (2012); ${ }^{12}$ Rojas-Graü and others (2007); ${ }^{13}$ McHugh and Olsen (2004); ${ }^{14}$ Shin and others (2014); ${ }^{15}$ Sothornvit and Pitak (2007); ${ }^{16}$ Martelli and others (2013); ${ }^{17}$ Martelli and others (2014); ${ }^{18}$ Martelli and others (2015); ${ }^{19}$ Dantas and others (2015); ${ }^{20}$ Azeredo and others (2012a); ${ }^{21}$ Azeredo and others (2012b); ${ }^{22}$ Farias and others (2012); ${ }^{23}$ Souza and others (2012): ${ }^{24}$ Reis and others (2015); ${ }^{25}$ Souza and others (2011); ${ }^{26}$ Eça and others (2015); ${ }^{27}$ Wang and others (201 1b); ${ }^{28}$ Wang and others (2011a); ${ }^{29}$ Andrade and others (2016); ${ }^{30}$ Wang and others (2012a); ${ }^{31}$ Wang and others (2012b); ${ }^{32}$ Wang and others (2012c); ${ }^{33}$ Park and Zhao (2006); ${ }^{34}$ Mariniello and others (2007); 35 Wang and others (2012d); ${ }^{36}$ Deng and Zhao (2011); ${ }^{37}$ Hayashi and others (2006); ${ }^{88}$ Lorevice and others (2012); ${ }^{39}$ Mattoso and others (2015); ${ }^{40}$ Azeredo and others (2009); 41 Sothornvit and Rodsamran (2010a);

${ }^{42}$ Sothornvit and Rodsamran (2010b); ${ }^{43}$ Sothornvit and Rodsamran (2008); 44 Otoni and others (2014); 45 Lorevice and others (2014); 46 Tulamandi and others (2016); 47 Otoni and others (2015); 48 Wang and others (2012ee); ${ }^{49}$ Azeredo and others (2016); ${ }^{50}$ Peretto and others (2014); ${ }^{51}$ Friedman and others (2007); ${ }^{52}$ Du and others (2008a); ${ }^{53}$ Du and others (2009b); ${ }^{54}$ Xu and others (2017).

of the number of components and layers, most edible films based on fruits and vegetables contain the following components:

\section{Fruits and vegetables: Purees, pomaces, and extracts}

In line with the trend of obtaining materials featuring distinguished sensory and nutritional properties, fruits and vegetables have been used as primary ingredients for the production of edible films. More than 35 plant species have already been used to obtain edible films. The film-forming formulation (FFF) may be either exclusively comprised by the plant material or multicomponent. In both cases, the literature reports the use of fruits and vegetables mostly as purees, but also as extracts or juices or even food processing wastes or residues (regarded as pomaces in this text; Table 1).

Concerning fruit and vegetable by-products, it is a consensus that food processing operations may generate high amounts of residues. Most of these, though, are underutilized because of their low market value. Apple processing, for instance, generates over
9000 tons of apple peel each year (Shin and others 2014). In many cases, producers use food processing wastes as animal feed or fertilizer, or rather discard them into soil or landfills (Park and Zhao 2006), representing a potential environmental issue and a waste of potentially value-added products. Even if fruit and vegetable pomaces are not supposed to be sensory appealing, they are still potential sources of biomass and compounds with nutritional value. The biomass from fruit juice industry, for instance, is rich in pectin, dietary fibers, and phytochemicals (Park and Zhao 2006). Andrade and others (2016) took advantage of the pomace from production of an isotonic drink to produce edible films comprising orange, passion fruit, watermelon, lettuce, courgette, carrot, spinach, mint, taro, cucumber, and rocket. Alternate to using pomaces themselves, some components-pigments and phenolic compounds, to mention a few-have been extracted from food processing wastes. However, extraction procedures also generate residues and are not in line with the increasing trend of using the whole plant material. The use of such to produce edible 
films stands out as a feasible alternative to reduce the production cost of edible films and to add value to food by-products. Still, when the by-product is rich in lipids or low water-soluble hydrocolloids, it makes sense to extract the compounds of interest with any food-grade solvent - such as water-and add them to the FFF, although lipids may be desired for providing the final material with improved barrier to moisture (Deng and Zhao 2011).

\section{Binding agents}

Because film-forming polypeptides and polysaccharides are naturally present in many fruits and vegetables, there are a few reports of films produced only with fruit purees, including peach, apricot, pear, apple (McHugh and others 1996), mango (Sothornvit and Rodsamran 2008; Azeredo and others 2009; Sothornvit and Rodsamran 2010b), and banana (Martelli and others 2015). Carrot, for instance, mainly consists of water, protein, cellulosic and pectic substances, which can lead to free-standing films (Wang and others 2011b). However, films comprised exclusively of puree frequently present poor consistency, mechanical strength and barrier properties, so edible hydrocolloids are added as binding agents to improve films' physical properties. In some cases, the purees themselves form layers that cannot even be detached from the cast surface as continuous films (McHugh and Senesi 2000; Park and Zhao 2006; Lorevice and others 2012, 2014), making the addition of these biomacromolecules of utmost importance in order to increase film cohesiveness. Pectin has been by far the most used binding agent in edible films based on fruits and vegetables (Table 2), but the use of other matrices has been reported. If the addition of a single biopolymer is not sufficient, 2 or more macromolecules may be combined into blends, as in carrot films (Wang and others 2011b). These biomacromolecules can be extracted from plants (for example, starch, pectin, and cellulose), animals (collagen, gelatin, and chitosan), microorganisms (for instance, bacterial cellulose), and algae (including alginate and carrageenan).

The chemical structures of the hydrocolloids are expected to influence their film-forming abilities. Low-methoxyl pectin, for instance, was shown to produce stronger and less extensible cranberry pomace-added films than its high-methoxyl counterpart (Park and Zhao 2006). Likewise, the substitution degrees in cellulose derivatives, - such as carboxymethylcellulose (CMC), hydroxypropyl methylcellulose (HPMC), and methylcellulose (MC) - , amino acid sequences in proteins, deacetylation degrees in chitosan, and amylose/amylopectin ratio in starch - to mention a few-are critical factors to determine the physical behavior of films. Gelatin has good gelling and film-forming abilities as well as a melting temperature close to that of the human body, providing the consumer with a good sensation because of its melt-in-mouth behavior. Gelatin may be obtained from the partial denaturation of collagen. When extracted from fish, particularly, gelatin consumption is even broader because it is kosher and halal (Otoni and others 2012). Gelatin films are known to exhibit good mechanical and gas barrier properties, but they are generally too brittle, making the addition of plasticizers essential for their practical application (Wang and others 2011b).

\section{Plasticizers}

Plasticizers can be either part of the polymer macromoleculesinternal-or low molecular weight, nonvolatile substances that do not chemically bind to the backbone chain-external(Sothornvit and Krochta 2005), both of them being intended
Table 2-Food-grade biopolymers and plasticizers used for formulating edible films based on fruits and vegetables.

\begin{tabular}{|c|c|c|}
\hline Biopolymer & Plasticizer & References \\
\hline \multirow[t]{3}{*}{ Cassava starch } & Glycerol & $\begin{array}{l}\text { Amaral and others }(2010) ; \\
\text { Souza and others }(2011) ; \\
\text { Farias and others }(2012) ; \\
\text { Dantas and others }(2015) \\
\text { Reis and others }(2015)\end{array}$ \\
\hline & Sucrose & $\begin{array}{l}\text { Hayashi and others (2006); } \\
\text { Souza and others }(2012)\end{array}$ \\
\hline & Inverted sugar & $\begin{array}{l}\text { Hayashi and others (2006); } \\
\text { Souza and others (2011, } \\
2012 \text { ) }\end{array}$ \\
\hline Chitosan & Glycerol & Wang and others (2011a) \\
\hline Carboxymethylcellulose & Glycerol & Wang and others (2011 b) \\
\hline Corn starch & Glycerol & $\begin{array}{l}\text { Wang and others (2011 a); } \\
\text { Wang and others }(2011 \mathrm{~b}) ; \\
\text { Xu and others (2017) }\end{array}$ \\
\hline Gelatin & Glycerol & $\begin{array}{l}\text { Wang and others (201 1a); } \\
\text { Wang and others }(2011 \mathrm{~b}) ; \\
\text { Shin and others }(2014) ; \\
\text { Tulamandi and others } \\
\text { (2016); Liu and others } \\
\text { (2017) }\end{array}$ \\
\hline \multirow[t]{3}{*}{ High-methoxyl pectin } & Glycerol & $\begin{array}{l}\text { McHugh and Senesi (2000); } \\
\text { Park and Zhao (2006); } \\
\text { Rojas-Graü and others } \\
\text { (2006); Ravishankar and } \\
\text { others (2009); Ravishankar } \\
\text { and others (2012); Espitia } \\
\text { and others (2014a, } \\
\text { 2014b); Peretto and others } \\
\text { (2014); Azeredo and others } \\
\text { (2016) }\end{array}$ \\
\hline & Sorbitol & Park and Zhao (2006) \\
\hline & - & $\begin{array}{l}\text { Du and others (2008a, } \\
2009 \mathrm{~b}) ; \text { Otoni and others } \\
(2014)\end{array}$ \\
\hline HPMC & - & $\begin{array}{l}\text { Lorevice and others (2012, } \\
\text { 2014); Otoni and others } \\
(2015)\end{array}$ \\
\hline \multirow[t]{3}{*}{ Low-methoxyl pectin } & Glycerol & $\begin{array}{l}\text { Deng and Zhao (2011); Du } \\
\text { and others (2008b, 2009a, } \\
2011) ; \text { Eca and others } \\
\text { (2015); Mattoso and others } \\
\text { (2015); Park and Zhao } \\
(2006)\end{array}$ \\
\hline & Sorbitol & Park and Zhao (2006) \\
\hline & & Otoni and others (2014) \\
\hline Methylcellulose & Glycerol & Shin and others (2014) \\
\hline Phaseolin & - & Mariniello and others (2007) \\
\hline Polylactide & Glycerol & Shin and others (2014) \\
\hline Ticafilm ${ }^{\circledR}$ a & Glycerol & Deng and Zhao (2011) \\
\hline \multirow[t]{2}{*}{ Sodium alginate } & Glycerol & $\begin{array}{l}\text { Deng and Zhao (2011); } \\
\text { Rojas-Graü and others } \\
(2007)\end{array}$ \\
\hline & Corn syrup & $\begin{array}{l}\text { Azeredo and others (2012a); } \\
\text { Azeredo and others } \\
(2012 a)\end{array}$ \\
\hline Soy protein & Glycerol & Tulamandi and others (2016) \\
\hline
\end{tabular}

a Ticafilm ${ }^{\circledR}$ is a mixture of sodium alginate, carrageenan, and cellulose gum.

to make polymer processing easier and/or to modify the properties of the resulting material. External plasticizers, particularly, reduce the polymer chain-to-chain interaction level by positioning themselves between polymer molecules and thus separating adjacent chains apart. This action leads to materials with reduced brittleness and stiffness as well as increased flexibility, stretchability, and toughness (Han and Aristippos 2005; Sothornvit and Pitak 2007). Nonetheless, because free volume and molecular mobility are higher after plasticizer addition, these compounds impair film barrier properties (Sothornvit and Krochta 2005).

As pointed out previously, most edible films are too brittle because of extensive intermolecular forces that hold polymer chains together (Wang and others 2011b), namely, hydrogen, 
hydrophobic or disulfide bonding as well as electrostatic interactions. Food-grade plasticizers commonly used in edible films have been extensively reviewed elsewhere (Sothornvit and Krochta 2005), whereas those used in the production of edible films based on fruits and vegetables are summarized in Table 2. Glycerol (or vegetable glycerin) is noticeably the most used plasticizer for this purpose. Indeed, glycerol-a small polyol with 3 hydroxyl groupshas been pointed out as the best plasticizer for water-soluble polymers (Jangchud and Chinnan 1999). When compared to sorbitol, glycerol has a higher plasticizing efficiency, while sorbitolplasticized pectin films were denser, more resistant, and less extensible (Park and Zhao 2006). These traits might result from sorbitol's higher molecular weight and solid characteristics at room temperature, while glycerol is liquid. On the other hand, Shen and others (2015) reported better results for sorbitol than glycerol when plasticizing polyvinyl alcohol (PVOH)-sugar beet pulp edible films, which otherwise were too brittle and cracked on the casting surface. Glycerol-plasticized films were wet and difficult to peel from the casting surface. As a matter of fact, high glycerol contents have been reported to migrate to film surface, exudate, and form sticky films (Wang and others 2011b).

Wang and others (2011b) reported unplasticized carrot pureeadded CMC-, gelatin-, and starch-based films to be brittle and rigid as well as to have holes and cracks, whereas glycerolplasticized films were more flexible. These authors observed reduced tensile strength as well as increased elongation at break and WVP of carrot edible films as glycerol content was increased. McHugh and Senesi (2000) added glycerol to apple films not only for plasticizing purposes but also to reduce film adhesion to the casting surface.

Other food-grade plasticizers may also be used for edible film production, including low-molecular weight sugars (for example, fructose-glucose syrups and honey), other polyols (for instance, glyceryl derivatives and propylene glycols), lipids and derivatives (including phospholipids, fatty acids, lecithin, oils, and waxes), and water (Han and Aristippos 2005; Sothornvit and Krochta 2005). Corn syrup has been used both as plasticizer and sweetener to acerola films and coatings, which otherwise were too acidic (Azeredo and others 2012a; Azeredo and others 2012b).

Mono-, di-, and oligosaccharides- present in fruits and vegetables have been demonstrated to act as natural plasticizers (McHugh and others 1996; Veiga-Santos and others 2007; Rouilly and others 2009; Silva and others 2012; Espitia and others 2014). Edible films based on papaya (Lorevice and others 2014; Otoni and others 2014), tomato (Du and others 2008a, 2009b), and guava (Lorevice and others 2012) purees featuring good mechanical properties have been produced without the addition of plasticizers other than the purees. Otoni and others (2014) observed that the tensile strength and elastic modulus of pectin films were reduced whereas the elongation at break and WVP were increased upon addition of papaya puree, corroborating that the puree presented a plasticizing effect. Similar observations were made for systems comprising HPMC and guava (Lorevice and others 2012), papaya (Lorevice and others 2014), and peach (Otoni and others 2015) purees, cassava starch and mango (Souza and others 2012; Reis and others 2015), and acerola (Souza and others 2012) purees.

Decreased glass transition temperature $\left(T_{g}\right)$ was observed for mango puree-based films, which was attributed to the plasticizing effect of simple sugars (Azeredo and others 2009). Sothornvit and Pitak (2007) pointed out that sucrose from banana puree is capable of plasticizing polymer films. Accordingly, Martelli and others (2013) had to add glycerol to films produced from centrifuged over-ripe banana/water and attributed this to the partial sugar removal by centrifugation.

\section{Fillers}

Most biopolymers commonly used as binding agents in edible films based on fruits and vegetables are widely known to exhibit poor mechanical resistance, barrier and thermal properties, especially if compared to conventional polymers. Materials featuring these characteristics have limited commercial applicability for food packaging purposes. A feasible strategy to overcome this technical hurdle is the production of edible composites/nanocomposites by addition of reinforcing fillers.

Polymer nanocomposites are mixtures of polymers with nanoparticles. Polymer nanoreinforcements are nanoparticles added to polymers in order to obtain nanocomposites with enhanced mechanical and other physical properties. A uniform nanoparticle dispersion within a polymer matrix leads to a very large matrix/filler interfacial area, which changes the molecular mobility, the relaxation behavior, and the resulting thermal and tensile properties of the material. Fillers with high aspect ratios are particularly interesting because of their high specific surface area, providing better reinforcement effects. Polysaccharide nanoparticles-especially cellulose nanostructures - have been presented as good renewable and biodegradable nanofillers, due to their partly crystalline structures, providing an extremely high strength as well as good reinforcement effects (Azeredo and others 2017). Cellulose nanocrystals (CNCs) - or whiskers-can be obtained by acid hydrolysis of cellulosic materials, removing the amorphous regions of cellulose, and leaving the crystalline regions relatively intact (Gardner and others 2008). Microcrystalline cellulose (MCC) has a similar structure, formed by hydrolyzed cellulose consisting of a large amount of cellulose nanocrystals and amorphous areas (Petersson and Oksman 2006).

MCC has been added to mango puree-based films (Azeredo and others 2009), resulting in improvement of tensile propertiesespecially elastic modulus-and reduction of WVP of the films. CNCs have been incorporated into films and coatings from acerola puree and alginate (Azeredo and others 2012a; Azeredo and others 2012b), resulting in enhanced tensile and barrier properties of the films (Azeredo and others 2012b), and decreased weight loss, decay incidence, ascorbic acid degradation, and ripening rates of coated acerolas (Azeredo and others 2012a). Montmorillonite (MMT) nanoclays were also incorporated into alginate-acerola puree coatings, and the effects of MMT and CNC on those coatings were compared (Arezedo and others 2012a). Both nanocomposite coatings presented similar effects on extending acerola shelflife, the MMT-containing coating presenting a brighter red color, which was ascribed to a stabilization effect of MMT on anthocyanins from acerola puree. Different nanoclays (Cloisite $\mathrm{Na}^{+}$, $30 \mathrm{~B}$, and 20A) have also been incorporated into apple peelbased edible films for reinforcement purposes (Shin and others 2014).

Chitosan is a polysaccharide obtained through the deacetylation of chitin that has been used as both matrix (Table 2) and fillerchitosan nanoparticles, particularly (Lorevice and others 2016)-in edible films. Banana puree edible films presented a $40 \%$ increase in tensile strength as well as decreased WVP when $0.2 \mathrm{wt} \%$ of chitosan nanoparticles was incorporated (Martelli and others 2013). The mechanical and water barrier properties of edible films based on papaya and guava (Lorevice and others 2012, 2014) purees were improved by chitosan nanoparticles. 


\section{Functional additives}

Edible films based on fruits and vegetables may carry functional compounds intended to provide the packaged product or the packaging material itself with improved characteristics (sensory, nutritional, and/or microbiological, to mention a few), thus playing an active role by interacting with foodstuffs. Antimicrobial compounds have been especially used in edible films based on fruits and vegetables. The incorporation of essential oils and oil compounds produced as secondary metabolites by numerous plant species into active food packaging has been extensively reviewed elsewhere (Valdes and others 2015; Atares and Chiralt 2016; Otoni and others 2016). These were reported to have both antimicrobial (Atares and Chiralt 2016) and antioxidant effects (Amorati and others 2013)

Essential oils that have been incorporated into edible films based on fruits and vegetables for antimicrobial purposes include those extracted from allspice (Du and others 2009a, 2008a), cinnamon (Rojas-Graü and others 2006, 2007; Du and others 2009a), clove bud (Du and others 2009a), garlic (Du and others 2009b), lemongrass (Rojas-Graü and others 2006, 2007), oregano (Rojas-Graü and others 2006, 2007; Du and others 2009b; Wang and others 2011a), and thyme (Espitia and others 2014a, 2014b). In several studies, authors have used the major compounds of those essential oils, namely, carvacrol (Friedman and others 2007; Rojas-Graü and others 2007; Du and others 2008a, 2008b; Ravishankar and others 2009; Wang and others 2011a; Du and others 2012; Ravishankar and others 2012; Peretto and others 2014; Zhu and others 2014), cinnamaldehyde (Rojas-Graü and others 2007; Ravishankar and others 2009; Wang and others 2011a; Du and others 2012; Ravishankar and others 2012; Otoni and others 2014; Zhu and others 2014), and citral (Rojas-Graü and others 2007; Wang and others 2011a). The major components of oregano and cinnamon essential oils, for instance, are carvacrol (Du and others 2009b) and cinnamaldehyde (Du and others 2009a), respectively. These compounds are designated as "generally regarded as safe" (GRAS; Rojas-Graü and others 2006; Espitia and others 2014a, 2014b), which is mandatory for edible applications.

The natural antimicrobials tested in edible films based on fruits and vegetables are not limited to essential oils and oil compounds. Polyphenols-including tannins, flavonoids, and phenolic acids derivatives-are also plant secondary metabolites with antimicrobial effects (Espitia and others 2014b). Besides, they are known to scavenge active oxygen in human body as well as to exert several biological functions such antioxidative, anticarcinogenic, antiinflammatory, and antiatherosclerogenic, among others ( $\mathrm{Du}$ and others 2011). Polyphenols extracted from various sources, including fruits and vegetables, have been incorporated into antimicrobial edible films and coating (Cagri and others 2004). Concerning edible films based on fruits and vegetables, specifically, GRAS apple skin polyphenols have been added to edible films made up of açaí (Espitia and others 2014a, 2014b) and apple (Du and others 2011) purees. Also because of its high contents of phenolics, yerba mate extract possesses a strong antioxidant activity, which motivated its addition into mango puree edible films (Reis and others 2015). Lastly, methyl cinnamate (a major volatile from strawberry) is a GRAS methyl ester of cinnamic acid that has been incorporated into strawberry puree edible films as an antifungal agent (Peretto and others 2014).

A major concern regarding some functional additives is their strong, unusual flavor/aroma. Although sensory evaluation of edible films and foodstuffs packaged within them is scarce (though highly recommended), many active compounds are known to be widely accepted by consumers. Cinnamon and oregano essential oils, for instance, have sensory compatibility with various food products and edible films, being used even as food flavorings (Rojas-Graü and others 2006; Du and others 2009a, 2012; Zhu and others 2014). An interesting strategy is to pack fruits and vegetables using edible films based on or incorporated with compounds extracted from the same plant materials, as has been done with apple (McHugh and Senesi 2000), strawberry (Peretto and others 2014), and mango (Sothornvit and Rodsamran 2008, 2010a, 2010b).

\section{Other additives}

Fruits and vegetables rich in phenolic components are readily subjected to the action of polyphenol oxidase upon cutting, peeling, and/or pulping (Yoruk and Marshall 2003). Other browning reactions (Maillard reaction, for example) may also take place if temperature is increased and reducing sugars are present. Browning may be undesirable due to sensory changes and decreased nutritional value (Martins and others 2000; Yoruk and Marshall 2003), and may be prevented by the addition of browning inhibitors. Ascorbic and citric acids were used to prevent browning in edible films from apple (McHugh and Senesi 2000; Rojas-Graü and others 2006; Du and others 2008b, 2009a, 2011; Ravishankar and others 2012), açaí (Espitia and others 2014a, 2014b), banana (Martelli and others 2014), carrot, and hibiscus (Ravishankar and others 2012). Browning reactions in carrot puree-based edible films were avoided by acetic acid and sodium bicarbonate (Wang and others 2011a). Sodium chloride is another salt that has been used for the same purpose, in just-sliced bananas (Sothornvit and Pitak 2007). Finally, Rojas-Graü and others (2007) have added Nacetylcysteine to prevent browning of glycerol-plasticized sodium alginate/apple puree edible films.

Crosslinkers are another class of additives that may be present in fruit- and vegetable-based FFFs. Crosslinking of polymer matrices links adjacent chains together by covalent bonds, usually resulting in stronger and less permeable films (Porta and others 2011). This crosslinking can be achieved either physically (Benbettaïb and others 2016) - by submitting the macromolecule to physical treatments that induce formation of a tridimensional network, such as $\gamma$ (Porta and others 2011) and ultraviolet-B (Otoni and others 2012) radiations - or chemically — by adding food-grade crosslinking agents, such as enzymes, particularly transglutaminase (Porta and others 2011). Several crosslinking agents are present on fruit and vegetable purees. Approximately $1 / 4$ of wine grape pomace weight, for instance, has been assigned to crosslinking agents, including minerals (such as $\mathrm{Ca}^{2+}, \mathrm{Mg}^{2+}$, and $\mathrm{Fe}^{3+}$ ), proteins as well as organic, amino, and phenolic acids (Deng and Zhao 2011). These naturally occurring crosslinkers could eliminate the need of additional crosslinkers to produce films from wine grape pomace extract, but their effects on films' physical properties have been hardly explored in the literature. Mariniello and others (2007) used microbial transglutaminase to crosslink fennel-waste films and achieved decreased WVP as well as increased resistance and stiffness. In contrast, McHugh and others (1996) added calcium chloride to peach puree in order to crosslink pectin chains in an effort to reduce the WVP, but the WVP of the resulting film increased instead, which the authors attributed to the increased ionic strength and solubility coefficient of the crosslinked films. Many other compounds-including formaldehyde and glutaraldehydeare able to induce crosslinking of polymer chains, but most of them are nonfood grade and/or toxic so their use in edible films is ruled out. 


\section{Film-Forming Procedures \\ Film-forming formulations}

The 1st step of a film-forming protocol is the production of a film-forming solution, dispersion or suspension-generically regarded in this text as FFFs. All components must be intimately mixed in order to obtain homogeneous edible films. Proper mixtures of the components have been achieved through low-speed stirring (Du and others 2008a, 2008b, 2009a, 2009b, 2011; Deng and Zhao 2011; Lorevice and others 2012, 2014; Espitia and others 2014a); combination of stirring and ultrasound cell disruption (Azeredo and others 2012a; Azeredo and others 2012b); moderatespeed stirring (Park and Zhao 2006; Deng and Zhao 2011; Otoni and others 2014); high-speed stirring (Rojas-Graü and others 2006, 2007; Du and others 2008a, 2008b, 2009a, 2009b; Ravishankar and others 2009; Du and others 2011; Wang and others 2011a; Wang and others 2011b; Ravishankar and others 2012; Espitia and others 2014a; Peretto and others 2014; Shin and others 2014); and high-pressure microfluidization (Shin and others 2014). The FFF components as well as their roles in the resulting edible films are discussed below.

\section{Degassing of film-forming formulations}

Degassing and defoaming of FFFs is an important step of production of polymer films, in order to remove air microbubbles, which, if left suspended, tend to remain entrapped within the dried film, acting as structural defects that cause mechanical failures. Vacuum degassing, used by most authors, varies in intensity and time depending on the viscosity of the formulation, and is more effective when performed under heating. Vacuum degassing times applied to fruit and vegetable FFFs have ranged from $15 \mathrm{~min}$ (Du and others 2008a, 2008b, 2009a, 2011; Wang and others 2011a; Wang and others 2011b) to almost $60 \mathrm{~min}$ (Peretto and others 2014). Azeredo and others (2012b) reported $30 \mathrm{mbar}$ and $45 \mathrm{~min}$ to effectively remove bubbles from a corn syrup-plasticized sodium alginate-acerola puree solution.

There are a few reports on bubble elimination by simply resting the FFF for $4 \mathrm{~h}$ (Lorevice and others 2012, 2014; Otoni and others 2014), but this procedure is only suitable for very lowviscosity formulations. Centrifugation is undoubtedly the most efficient method to degas highly viscous liquids, but it cannot be applied on formulation containing suspended solids. Ultrasonic degassing is another alternative for viscous samples. Reis and others (2015) removed air bubbles from a starch-mango puree dispersion by heating and shaking at $70^{\circ} \mathrm{C}$ for $10 \mathrm{~min}$ followed by ultrasonication.

\section{Casting}

To this date, there are no reports of production of edible films based on fruits and vegetables by a process other than casting, mainly because of the thermosensitivity of fruit/vegetable components as well as of the biopolymers themselves. Other film-forming procedures, such as slit-die extrusion, blown-film extrusion, and calendaring, involve high temperatures, which in turn lead to undesirable reactions that include degradation of biopolymers as well as nutritional and sensory losses in fruit/vegetable compounds. Production of edible films based on fruits and vegetables has been reported by both bench casting and continuous casting, the former being more widespread within the scientific community.

Bench casting. Film production by bench casting consists in pouring a FFF on rimmed or plain plates from varying materials. The final film thickness is controlled by the amount of suspension poured on rimmed plates or by using a draw-down bar (for plain plates). The solvent-usually water-is then evaporated, leaving the film-forming macromolecules to rearrange into a cohesive, free-standing layer. Although the basics of bench casting involve solvent removal through evaporation, the drying kinetics of these systems has not been the core subject of investigations to date. Parameters such as wet thickness, temperature, relative humidity (RH) and circulating air speed are critical, but these are not always reported in the literature, making the reproduction of some filmforming procedures difficult. Drying is usually carried out at room temperature or in air circulation ovens at temperatures not higher than 30 to $40{ }^{\circ} \mathrm{C}$, for 12 to $48 \mathrm{~h}$. Indeed, the long drying times are the most remarkable disadvantage of this technique, making it impracticable for industrial scale (Moraes and others 2013). Drying time has been reduced to 6 to $12 \mathrm{~h}$ upon temperature increase up to $60^{\circ} \mathrm{C}$ (Sothornvit and Pitak 2007; Wang and others 2011b), or even to 2 cycles of $40 \mathrm{~min}$ each in a laboratory padder at $60^{\circ} \mathrm{C}$ (Martelli and others 2013, 2014). Table 3 presents a compilation of the film-forming systems and parameters used to produce the edible films based on fruits and vegetables reported in the literature.

Continuous casting. Continuous film casting may be carried out on steel belt conveyors or on a coating line. In the 1st one, solutions are uniformly spread on a continuous steel belt that passes through a drying chamber. The dry film is then stripped from the steel belt and wound into mill rolls. One advantage of this technique is the ability to cast aqueous solutions directly onto the belt surface, optimizing uniformity, heat transfer, and drying efficiency, while avoiding expense of a separate substrate (Rossman 2009). In a coating line, such as a tape-casting machine, on the other hand, solutions are continuously spread onto a moving substrate- such as polyester or coated paper-with a blade whose height can be adjusted to control film thickness. The coated substrate then passes through a drying chamber. The dry film is wound into rolls while still adhered to the substrate (Rossman 2009; Moraes and others 2013).

Edible films based on fruits and vegetables have been produced by using a coating line (Mathis Labcoater unit, Werner Mathis AG, Zürich, Switzerland). This concept may be considered a scale-up of the previously described bench casting procedure, the major advantage of the former being the remarkably lower drying times, thanks to the use of an infrared (IR) radiation predrying stage, much higher temperatures, and intense air circulation. Du and others (2008a) produced tomato puree edible films in $12 \mathrm{~min}$ by casting a 1.04-mm-thick layer of FFF onto a Mylar ${ }^{\circledR}$ sheet and conveying it at $0.11 \mathrm{~m} / \mathrm{min}$ through 2 stages: an IR heater on the top of the FFF ( $4 \mathrm{~min}$ ) and an oven at $132{ }^{\circ} \mathrm{C}$ with air circulating perpendicularly to film surface at $1500 \mathrm{~m} / \mathrm{min}$ ( $8 \mathrm{~min}$ ). At the end, the film was cooled to room temperature and wound on a roller. Likewise, the same authors produced apple puree edible films (Du and others 2008b). Those films were also produced by bench casting at 23 to $25{ }^{\circ} \mathrm{C}$, the drying time being extended to about $16 \mathrm{~h}$. Mattoso and others (2015) used a similar procedure to produce glycerol-plasticized edible films based on watermelon, guava, and passion fruit from an initial wet thickness of 0.18 to $0.25 \mathrm{~mm}$ at $120{ }^{\circ} \mathrm{C}$ with a rolling speed of $0.12 \mathrm{~m} / \mathrm{min}$, forming film in a few minutes.

Other advantages of continuous casting are that it requires less space and labor and is more suitable for industrial applications ( Du and others 2008a). However, it may affect the physical properties of the resulting films. To exemplify, the retention of carvacrol was lower in continuous-cast apple puree edible films than in their bench-cast counterparts because of the higher temperatures 
Fruit and vegetable edible films...

Table 3-Parameters used in the production of edible films based on fruits and vegetables through bench casting.

\begin{tabular}{|c|c|c|c|c|c|c|}
\hline Fruit/vegetable & Binding agent & Casting surface & Temperature $\left({ }^{\circ} \mathrm{C}\right)$ & RH (\%) & Drying time $(\mathrm{h})$ & Reference \\
\hline Açaí & HM pectin & PET sheet & $23-25$ & ND & $12 \pm 1$ & 1 \\
\hline \multirow{2}{*}{ Acerola } & Cassava starch & PMMA plate & $30 \pm 1$ & 53 & $24-48$ & 2 \\
\hline & Sodium alginate & Glass plate & $24 \pm 1$ & $76 \pm 2$ & 24 & 3 \\
\hline Acerola and mango & Cassava starch & PS plate & $35 \pm 2$ & ND & $18-20$ & 4 \\
\hline $\begin{array}{l}\text { Acerola, mango, and } \\
\text { red mombin }\end{array}$ & Cassava starch & PS plate & 30 & ND & 20 & 5 \\
\hline \multirow{8}{*}{ Apple } & - & PMMA plate & $23-25$ & $40 \pm 2$ & $\sim 24$ & 6 \\
\hline & $\begin{array}{l}\text { CMC, gelatin, MC, and } \\
\text { PLA }\end{array}$ & Glass or PTFE plate & Room & ND & $>24$ & 7 \\
\hline & HM pectin & PET sheet & $23-25$ & ND & 14 & 8 \\
\hline & & PTFE plate & $24 \pm 1$ & $40 \pm 2$ & 24 & 9 \\
\hline & & ND & Room & ND & $\sim 24$ & 10 \\
\hline & & PET sheet & $23-25$ & ND & $\sim 14$ & 11 \\
\hline & LM pectin & Mylar ${ }^{\circledR}$ sheet & $20-25$ & ND & Overnight & $12-14$ \\
\hline & Sodium alginate & ND & Room & ND & $\sim 24$ & 15 \\
\hline Apricot & - & PMMA plate & $24 \pm 1$ & $40 \pm 2$ & $\sim 24$ & 6 \\
\hline \multirow[t]{2}{*}{ Banana } & Pectin & HDPE plate & 60 & ND & 12 & 16 \\
\hline & & Polyester sheet & 50 & ND & 1.33 & $17-18$ \\
\hline \multirow[t]{2}{*}{ Carrot } & $\begin{array}{l}\text { Chitosan, corn starch, } \\
\text { and gelatin }\end{array}$ & HDPE plate & 60 & ND & 6 & 19 \\
\hline & HM pectin & PET sheet & $23-25$ & ND & 14 & 8 \\
\hline Cranberry & HM or LM pectin & PTFE sheet & $24 \pm 2$ & $40 \pm 5$ & 48 & 20 \\
\hline Fennel & Phaseolin & PS plate & 37 & ND & Overnight ${ }^{b}$ & 21 \\
\hline \multirow[t]{4}{*}{ Grape } & LM pectin & PTFE sheet & $24 \pm 2$ & $40 \pm 5$ & $36-48$ & 22 \\
\hline & Sodium alginate & PTFE sheet & $24 \pm 2$ & $40 \pm 5$ & $36-48$ & 22 \\
\hline & Ticafilm ${ }^{\circledR a}$ & PTFE sheet & $24 \pm 2$ & $40 \pm 5$ & $36-48$ & 22 \\
\hline & Corn starch & PTFE-coated plate & Room & ND & 72 & 35 \\
\hline Grape and spinach & Cassava starch & ND & 45 & ND & ND & 23 \\
\hline Guava & HPMC & PC plate & ND & ND & 24 & 24 \\
\hline Hibiscus & HM pectin & PET sheet & $23-25$ & ND & 14 & 8 \\
\hline \multirow[t]{2}{*}{ Mango } & - & Glass plate & 22 & 42 & 16 & 25 \\
\hline & - & HDPE plate & 50 & ND & 12 & $26-27$ \\
\hline $\begin{array}{l}\text { Mango and yerba } \\
\text { mate }\end{array}$ & Cassava starch & PS plate & 35 & ND & ND & 28 \\
\hline \multirow[t]{3}{*}{ Papaya } & HM or LM pectin & PET sheet & $25 \pm 2$ & ND & 48 & 29 \\
\hline & HPMC & ND & Room & ND & 48 & 30 \\
\hline & $\begin{array}{l}\text { Gelatin or soy protein } \\
\text { and starch }\end{array}$ & Glass plate & 40 & 23 & 18 & 31 \\
\hline Peach & - & PMMA plate & $24 \pm 1$ & $40 \pm 2$ & $\sim 24$ & 6 \\
\hline Pear & - & PMMA plate & $24 \pm 1$ & $40 \pm 2$ & $\sim 24$ & 6 \\
\hline Strawberry & HM pectin & Polyester sheet & Room & ND & $\sim 15$ & 32 \\
\hline Tomato & HM pectin & Mylar ${ }^{\circledR}$ sheet & $20-25$ & ND & $12-16$ & $33-34$ \\
\hline
\end{tabular}

RH, relative humidity; HM, high-methoxyl; PET, poly(ethylene terephthalate); ND, not disclosed; PMMA, poly(methyl methacrylate); PS, polystyrene; PTFE, polytetrafluoroethylene; CMC, carboxymethylcellulose; $M C$, methylcellulose; PLA, poly(lactic acid); LM, low-methoxyl; HDPE, high-density polyethylene; HPMC, hydroxypropyl methylcellulose; PC, polycarbonate.

${ }^{a}$ Ticafilm ${ }^{\circledR}$ is a mixture of sodium alginate, carrageenan, and cellulose gum.

${ }^{\mathrm{b}}$ Drying assisted by air circulation.

Cited literature: ${ }^{1}$ Espitia and others (2014a); ${ }^{2}$ Farias and others $(2012) ;{ }^{3}$ Azeredo and others (2012a); ${ }^{4}$ Souza and others $(2011) ;{ }^{5}$ Dantas and others $(2015) ;{ }^{6}$ McHugh and others $(1996) ;{ }^{7}$ Shin and others (2014); ${ }^{8}$ Ravishankar and others (2012); ${ }^{9}$ McHugh and Senesi (2000); ${ }^{10}$ Rojas-Graü and others (2006); ${ }^{11}$ Ravishankar and others (2009); ${ }^{12}$ Du and others (2008b); ${ }^{13}$ Du and others (2009a); ${ }^{14}$ Du and others (2011); ${ }^{15}$ Rojas-Graü and others (2007); ${ }^{16}$ Sothornvit and Pitak (2007); ${ }^{17}$ Martelli and others (2013); ${ }^{18}$ Martelli and others (2014); ${ }^{19}$ Wang and others (201 1 b)i ${ }^{20}$ Park and Zhao (2006); ${ }^{21}$ Mariniello and others (2007); ${ }^{22}$ Deng and Zhao (2011); ${ }^{23}$ Hayashi and others (2006); ${ }^{24}$ Lorevice and others (2012); ${ }^{25}$ Azeredo and others (2009); ${ }^{26}$ Sothornvit and Rodsamran (2008); ${ }^{27}$ Sothornvit and Rodsamran $(2010 \mathrm{~b}) ;{ }^{28}$ Reis and others (2015); ${ }^{29}$ Otoni and others (2014); ${ }^{30}$ Lorevice and others (2014); ${ }^{31}$ Tulamandi and others (2016); ${ }^{32}$ Peretto and others (2014); ${ }^{33}$ Du and others (2008a); ${ }^{34}$ Du and others (2009b); ${ }^{35} \mathrm{Xu}$ and others (2017).

(Du and others 2008b). Figure 3 presents 4 stages of the continuous casting apparatus.

\section{Properties of Edible Films Based on Fruits and Vegetables}

Stability and shelf-life

Edible films based on fruits and vegetables might be considered as dehydrated foods when it comes to legislation and stability criteria. Those films have sufficient nutrients to serve as substrates for microbial growth. Unless they are aseptically packaged within an external packaging material, stability should be maintained mainly by water removal. The peach puree edible films produced in the pioneer study of McHugh and others (1996) presented a water activity of 0.43 , which is low enough to avoid microbial growth. The same was not true for the puree itself, which had a water activity of 0.95 . Similarly, low water activity values (lower than 0.6) were reported for films from wine grape pomace extract (Deng and Zhao 2011) and from mango puree (Sothornvit and Rodsamran 2008). Such low water activity values make these films expected to be microbiologically stable as long as they are properly stored under dry conditions. Higher water activity values (0.66 to 0.70 ) were observed in thermoplastic starch (TPS) films added by mango, acerola, and red mombin purees (Dantas and others 2015). Sugar crystallization may also lead to unsuitable physical performance of edible films based on fruits and vegetables. This process was not observed in mango puree edible films by Sothornvit and Rodsamran (2008) for up to $3 \mathrm{mo}$ at $30^{\circ} \mathrm{C}$. However, no other studies have investigated the shelf-life of edible films based on fruits and vegetables, although this information is essential for the successful commercialization of such products. As 

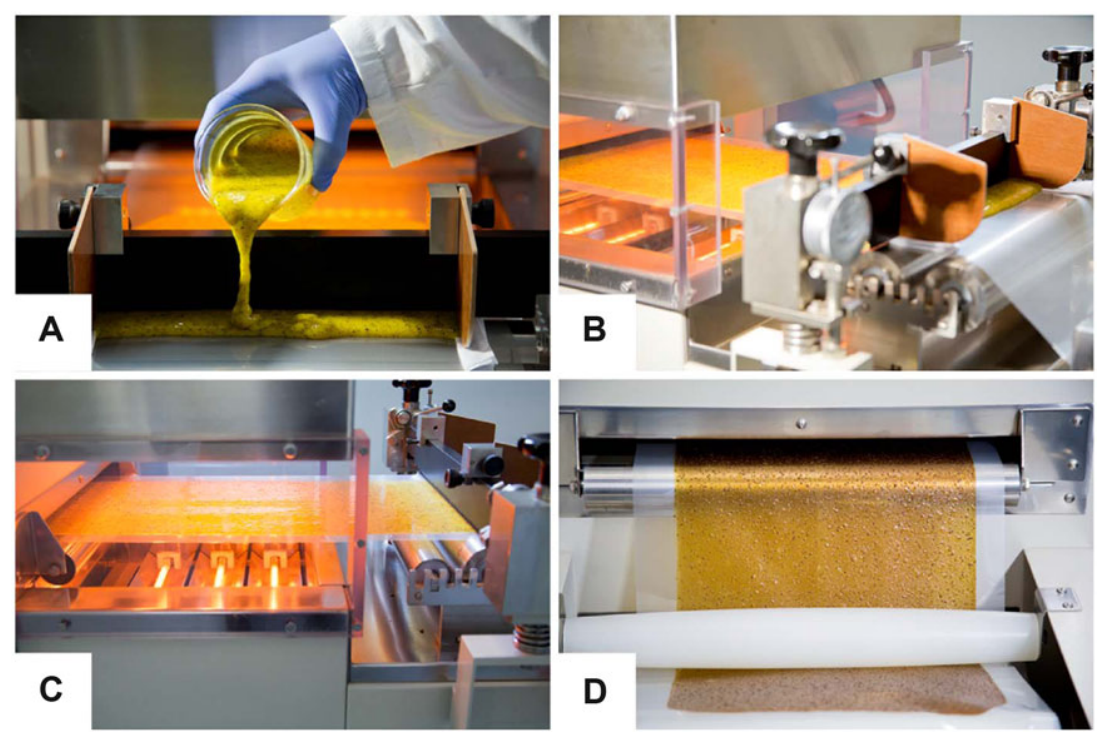

Figure 3-Production of a passion fruit film by continuous casting: film-forming formulation (FFF) manual feeding (A), which would be automated at industrial scale; substrate conveying the FFF through a blade of controlled thickness (B); IR radiation predrying (C); and film leaving the last drying stage and approaching the winding roll (D). This system may be freely adapted to the processing requirements of a specific film-forming procedure.

previously discussed, films are drier than purees, pomaces, extracts and juices, so they are expected to be more stable. This opens up the possibility of increasing stability of fruits and vegetables by means of drying them into films, which in turn might add value to agricultural crops during offseason. This approach is worth further exploitation in future studies.

\section{Mechanical properties}

Good mechanical properties are among the basic requirements for edible films to be used as food packaging, since poor flexibility or strength may lead to premature failure or cracking during production, handling, storage or use (Sothornvit and Rodsamran 2008).

Puncture force is a means of evaluating resistance to perforations. Farias and others (2012) observed that the puncture force of starchadded, glycerol-plasticized acerola edible films ranged from 3.7 to $13.3 \mathrm{~N}$, with lower binding agent contents and higher plasticizer contents leading to decreased puncture forces. Other important properties of films intended for food packaging are sealability and tear resistance. Sothornvit and Pitak (2007) obtained banana films with good sealability, and suggested that these films could be used as sachets or pouches for dry foods. Tulamandi and others (2016) produced papaya puree films added by starch and gelatin or soy protein that presented tear resistances and seal strengths ranging from 0.29 to $0.73 \mathrm{~g} / \mu \mathrm{m}$ and 127.3 to $726.0 \mathrm{~N} / \mathrm{m}$, respectively. Although penetration resistance, tear resistance, and seal strength are properties of great concern for packaging applications, these have not been widely investigated for edible films based on fruits and vegetables even if standard test methods F1306-16 (ASTM 2016), D1922-15 (ASTM 2015a), and F88 / F88M-15 (ASTM 2015b) have been proposed by the American Society for Testing and Materials.

The most investigated mechanical properties of edible films are those obtained in tensile tests, with emphasis on tensile strength, elastic modulus, and elongation. These attributes support the correlation of the mechanical properties of films to their compositions and chemical structures. The values of these mechanical attributes reported for edible films based on fruits and vegetables are compiled in Table 4.

The tensile strengths of edible films based on fruits and vegetables vary from values as low as 0.03 up to $30 \mathrm{MPa}$ (Table 4). Such values are comparable to those of some plastic films used in food packaging, such as low-density PE (LDPE, 8 to $10 \mathrm{MPa}$ ), high-density PE (HDPE, 19 to $31 \mathrm{MPa}$ ), ethylene-vinyl alcohol copolymer (EVOH, 6 to $19 \mathrm{MPa})$, PCL (4 MPa), but much smaller than those of polystyrene (PS, 31 to $49 \mathrm{MPa}$ ), poly(lactic acid) (PLA, $45 \mathrm{MPa}$ ), PVC (42 to $55 \mathrm{MPa}$ ), PP (27 to $98 \mathrm{MPa}$ ), and poly(ethylene terephthalate) (PET, 157 to $177 \mathrm{MPa}$ ). Likewise, the elastic modulus of edible films based on fruits and vegetables varies from $0.003 \mathrm{MPa}$ to $1.0 \mathrm{GPa}$ (Table 4), comparable to those of LDPE (150 to $340 \mathrm{MPa}$ ), PCL (386 MPa), and poly(vinylidene chloride) (PVDC, 200 to $600 \mathrm{MPa}$ ), but much smaller than PVC (2.8 GPa), PS (2.7 to $3.5 \mathrm{GPa})$, and PET ( $3.5 \mathrm{GPa})$. The elongation at break was reported to range from $1.8 \%$ to $217 \%$ (Table 4), being comparable to PS ( $2 \%$ to $3 \%)$, PVDC (10\% to $40 \%)$, HDPE (20\% to 50\%), PET (70\%), and PVC (20\% to $180 \%)$, but smaller than PP (200\% to $1000 \%)$, LDPE (300\% to $900 \%)$, and PCL $(800 \%$ to $1000 \%$; Gross and Kalra 2002; Bastarrachea and others 2011).

The mechanical properties of edible films strongly depend on their composition. Overall, vegetable films are expected to be stronger and less extensible than fruit films because of their higher ratios of dietary fibers to total sugars (McHugh and Olsen 2004). As discussed further in this review, there are applications of edible films based on fruits and vegetables in which their mechanical resistances and extensibilities are extremely important, but for some others these properties are not required. The mechanical properties of edible films based on fruits and vegetables can be adjusted as needed by addition of binding agents, fillers, crosslinkers and/or plasticizers. Higher fruit and vegetable contents are expected to lead to lower mechanical strength and stiffness as well as greater extensibility because of the plasticizing effects of short-chain sugars (Sothornvit and Pitak 2007; Lorevice and others 2012; Martelli and others 2013; Lorevice and others 2014; Otoni and others 
Table 4-Mechanical properties and test conditions of edible films based on fruits and vegetables, determined by tensile tests.

\begin{tabular}{|c|c|c|c|c|c|c|c|c|}
\hline Fruit/vegetable & Binding agent & $\mathrm{T}\left({ }^{\circ} \mathrm{C}\right)$ & $\begin{array}{c}\mathrm{RH} \\
(\%)\end{array}$ & $\begin{array}{l}\text { Crosshead } \\
\text { speed } \\
\text { (mm/min) }\end{array}$ & $\begin{array}{l}\text { Tensile } \\
\text { strength } \\
\text { (MPa) }\end{array}$ & $\begin{array}{l}\text { Elastic modulus } \\
(\mathrm{MPa})\end{array}$ & $\begin{array}{l}\text { Elongation }{ }^{\mathrm{a}} \\
(\%)\end{array}$ & Reference \\
\hline Açaí & HM pectin & ND & ND & 10.0 & $0.59-2.74^{a}$ & $3.17-13.36$ & $27.6-114.3$ & 1 \\
\hline \multirow[t]{2}{*}{ Acerola } & Cassava starch & ND & $50 \pm 3$ & 60.0 & $0.77-3.97$ & ND & $23.1-44.6$ & 2 \\
\hline & Sodium alginate & ND & 50 & 10.0 & $3.16-6.10^{b}$ & $15.36-50.58$ & $16.6-28.3$ & 3 \\
\hline Acerola and mango & Corn starch & 23 & 60 & 12.5 & $1.66-4.51$ & ND & $68.7-72.4$ & 4 \\
\hline $\begin{array}{l}\text { Acerola, cashew } \\
\text { apple, papaya, } \\
\text { pequi, and } \\
\text { strawberry }\end{array}$ & LM pectin & 25 & 58 & 60.0 & $7.00-10.70$ & $235.00-391.00$ & $6.8-10.8$ & 5 \\
\hline \multirow[t]{7}{*}{ Apple } & $\begin{array}{l}\text { CMC, gelatin, } \mathrm{MC} \text {, and } \\
\text { PLA }\end{array}$ & 25 & 50 & 500.0 & $9.00-20.00^{a}$ & ND & $4.0-5.5$ & 6 \\
\hline & HM pectin & $23 \pm 2$ & $50 \pm 2$ & 7.5 & $0.54-0.79^{b}$ & $4.04-5.58$ & $22.6-27.4$ & 7 \\
\hline & & $23 \pm 2$ & $33 \pm 2$ & 7.5 & $2.96-3.69$ & $4.15-5.28$ & $47.0-49.9$ & 8 \\
\hline & LM pectin & $23 \pm 2$ & $50 \pm 2$ & 7.5 & $1.25-1.93$ & ND & $38.1-50.3$ & 9 \\
\hline & & $23 \pm 2$ & $50 \pm 2$ & 7.5 & $2.85-3.63$ & $3.66-5.16$ & $48.6-54.0$ & 10 \\
\hline & & $23 \pm 2$ & 50 & 7.5 & $2.20-2.90^{\mathrm{b}}$ & $2.29-9.05$ & $38.2-42.2$ & 11 \\
\hline & Sodium alginate & $23 \pm 2$ & $50 \pm 2$ & 7.5 & $2.47-2.90^{\mathrm{b}}$ & $7.75-7.07$ & $51.1-58.3$ & 12 \\
\hline \multirow[t]{4}{*}{ Banana } & - & ND & 54 & ND & $0.26-0.42$ & ND & $13.0-17.0$ & 13 \\
\hline & Pectin & $23 \pm 2$ & $50 \pm 5$ & 50.0 & $2.50-15.00$ & $0.50-10.00$ & $3.0-16.5$ & 14 \\
\hline & & ND & 58 & 80.0 & $1.30-6.90^{b}$ & $4.00-120.00$ & $10.0-31.0$ & 15 \\
\hline & & ND & 58 & 80.0 & $1.30-6.00^{b}$ & $4.00-120.00$ & $10.0-27.0$ & 16 \\
\hline \multirow[t]{2}{*}{ Carrot } & $\begin{array}{l}\mathrm{CMC} \text {, corn starch, and } \\
\text { gelatin }\end{array}$ & $23 \pm 2$ & $50 \pm 1$ & 50.0 & $5.06-11.73^{b}$ & ND & $7.1-21.9$ & 17 \\
\hline & $\begin{array}{l}\text { Chitosan, corn starch, } \\
\text { and gelatin }\end{array}$ & 23 & $50 \pm 1$ & ND & $3.91-12.68^{b}$ & ND & $17.1-29.0$ & 18 \\
\hline Cranberry & HM or LM pectin & 25 & 50 & 30.0 & $1.00-8.10^{\mathrm{b}}$ & ND & $12.9-47.7$ & 19 \\
\hline Fennel & Phaseolin & $23 \pm 2$ & $50 \pm 5$ & 30.0 & $1.90-4.00^{\mathrm{b}}$ & $122.00-203.00$ & $7.3-9.0$ & 20 \\
\hline Grape & $\begin{array}{l}\text { LM pectin, sodium } \\
\text { alginate, and } \\
\text { Ticafilm }{ }^{\circledR} c\end{array}$ & 25 & $47 \pm 2$ & 24.0 & $1.12-4.04^{b}$ & ND & $9.9-25.1$ & 21 \\
\hline Grape and spinach & Corn starch & 23 & 75 & ND & $1.80-4.20$ & ND & $65.0-217.0$ & 22 \\
\hline Guava & HPMC & 23 & 30 & 50.0 & $5.40-12.20^{b}$ & ND & $2.2-8.1$ & 23 \\
\hline Isotonic drink residue & - & ND & ND & 60.0 & $0.027-0.084^{a}$ & $0.003-0.004$ & $30.5-34.5$ & 24 \\
\hline \multirow[t]{2}{*}{ Mango } & - & $23 \pm 2$ & $50 \pm 2$ & 7.5 & $4.09-8.76$ & $19.85-322.05$ & $31.5-44.1$ & 25 \\
\hline & - & 23 & $50 \pm 5$ & 50.0 & 1.20 & 8.30 & 18.5 & 26 \\
\hline $\begin{array}{l}\text { Mango and yerba } \\
\text { mate }\end{array}$ & Cassava starch & $23 \pm 2$ & $60 \pm 2$ & ND & $1.36-4.03$ & ND & $55.1-69.4$ & 27 \\
\hline \multirow[t]{3}{*}{ Papaya } & HM or LM pectin & ND & $33 \pm 2$ & 100.0 & $4.98-8.36$ & $30.00-125.26$ & $13.9-24.6$ & 28 \\
\hline & HPMC & 25 & ND & 50.0 & $20.10-30.80$ & ND & $2.9-8.4$ & 29 \\
\hline & $\begin{array}{l}\text { Gelatin or soy protein } \\
\text { and starch }\end{array}$ & ND & $50 \pm 5$ & 500.0 & $5.21-6.80$ & ND & $13.1-28.1$ & 30 \\
\hline Pomegranate & HM pectin & 24 & 50 & 60.0 & $3.37-7.77^{a}$ & $7.58-45.67$ & $8.4-20.1$ & 31 \\
\hline Strawberry & HM pectin & $23 \pm 2$ & $50 \pm 2$ & 7.5 & $2.07-2.38^{b}$ & $4.26-5.18$ & $56.2-56.7$ & 32 \\
\hline Sugar beet & - & 23 & $0-93$ & ND & $0.70-10.24$ & $112.00-1000.00$ & $1.8-7.4$ & 33 \\
\hline \multirow[t]{2}{*}{ Tomato } & HM pectin & $23 \pm 2$ & $33 \pm 2$ & 7.5 & $8.90-14.80$ & $187.20-465.20$ & $6.0-11.6$ & 34 \\
\hline & & $23 \pm 2$ & $50 \pm 2$ & 7.5 & $6.61-9.16$ & $44.80-68.70$ & $29.4-32.2$ & 35 \\
\hline
\end{tabular}

T, temperature; RH, relative humidity; HM, high-methoxyl; ND, not disclosed; LM, low-methoxyl; CMC, carboxymethylcellulose; MC, methylcellulose; PLA, poly(lactic acid); HPMC, hydroxypropyl methylcellulose. a Measured at break.

${ }^{b}$ Maximum stress during the tensile testing.

${ }^{\mathrm{C}}$ Ticafilm ${ }^{\circledR}$ is a mixture of sodium alginate, carrageenan, and cellulose gum.

$\mathrm{d}_{\text {Fruits }}$ and vegetables used in the isotonic drink formulation: orange, passion fruit, watermelon, lettuce, courgette, carrot, spinach, mint, taro, cucumber, and rocket.

Cited literature: ${ }^{1}$ Espitia and others (2014a); ${ }^{2}$ Farias and others (2012); ${ }^{3}$ Azeredo and others (2012a); ${ }^{4}$ Souza and others $(2012) ;{ }^{5}$ Eça and others (2015); ${ }^{6}$ Shin and others (2014); ${ }^{7}$ Rojas-Graü and others (2006); ${ }^{8}$ Ravishankar and others (2009); ${ }^{9}$ Du and others (2008b); ${ }^{10}$ Du and others (2009a); ${ }^{11}$ Du and others (2011); ${ }^{12}$ Rojas-Graü and others (2007); ${ }^{13}$ Martelli and others (2015); ${ }^{14}$ Sothornvit and Pitak (2007); ${ }^{15}$ Martelli and others (2013):i6 Martelli and others (2014); ${ }^{17}$ Wang and others (2011 b); ${ }^{18}$ Wang and others (201 1a); ${ }^{19}$ Park and Zhao (2006); ${ }^{20}$ Mariniello and others (2007); ${ }^{21}$ Deng and Zhao (2011); ${ }^{22}$ Hayashi and others (2006); ${ }^{23}$ Lorevice and others (2012); ${ }^{24}$ Andrade and others (2016); ${ }^{25}$ Azeredo and others (2009); ${ }^{26}$ Sothornvit and Rodsamran (2008); ${ }^{27}$ Reis and others (2015); ${ }^{28}$ Otoni and others (2014); ${ }^{29}$ Lorevice and others (2014); ${ }^{30}$ Tulamandi and others (2016); ${ }^{31}$ Azeredo and others (2016); ${ }^{32}$ Peretto and others (2014); ${ }^{33}$ Liu and others (2011); ${ }^{34}$ Du and others (2008a); ${ }^{35}$ Du and others (2009b).

2014, 2015; Reis and others 2015), although, the opposite behavior has been reported (Souza and others 2012; Martelli and others 2013). The latter outcome has been attributed to the presence of starch, cellulose derivatives, pectin, and other fibers. In the study carried out by Martelli and others (2013), specifically, banana puree showed a reinforcing effect, but its sugars had been partially removed by centrifugation. The additions of binding agents, fillers, and crosslinkers are also expected to reinforce edible films based on fruits and vegetables, whereas the opposite behavior has been observed for plant essential oils (Rojas-Graü and others 2006; Du and others 2009a; Espitia and others 2014a).

\section{Barrier properties}

Barrier to moisture. The biomacromolecules either naturally present in fruits and vegetables or added as binding agents usually have high polarity, hydrophilicity, and water holding capacity (Deng and Zhao 2011; Azeredo and others 2012a). These characteristics prevent such films from being good barriers to moisture, which is extremely important for food preservation (Shin and others 2014). The water barrier properties of edible films are commonly evaluated through gravimetric methods, in which the film acts as a semipermeable barrier between an environment of high RH and another of low RH, being water diffusion monitored 
Table 5-Water vapor permeability (WVP) of edible films based on fruits and vegetables.

\begin{tabular}{|c|c|c|c|c|c|c|}
\hline Fruit/vegetable & Binding agent & Method & $\begin{array}{l}\text { Temperature } \\
\left({ }^{\circ} \mathrm{C}\right)\end{array}$ & RH gradient (\%) & $\begin{array}{c}\text { WVP } \\
(\mathrm{g} \mathrm{mm} / \\
\left.\mathrm{m}^{2} / \mathrm{h} / \mathrm{kPa}\right)\end{array}$ & Reference \\
\hline \multirow[t]{2}{*}{ Açaí } & HM pectin & McHugh and others (1993) & ND & $78.3-84.9$ to ND & $2.56-3.55$ & 1 \\
\hline & & McHugh and others (1993) & ND & ND to 0 & 3.56 & 2 \\
\hline \multirow[t]{3}{*}{ Acerola } & Cassava starch & Turhan and Sahbaz (2004) & 25 & $N D$ to $50 \pm 3$ & $0.208-0.273$ & 3 \\
\hline & Sodium alginate & ASTM E96 & 24 & 85 to ND & $0.68-1.07$ & 4 \\
\hline & & ASTM E96 & 24 & 85 to ND & $0.41-0.87$ & 5 \\
\hline $\begin{array}{l}\text { Acerola, cashew apple, } \\
\text { papaya, pequi, and } \\
\text { strawberry }\end{array}$ & LM pectin & ASTM E96 & 25 & 65 to 33 & $0.10-0.16$ & 6 \\
\hline \multirow[t]{8}{*}{ Apple } & - & McHugh and others (1993) & $25 \pm 1$ & 76 to 0 & 5.84 & 7 \\
\hline & HM Pectin & McHugh and others (1993) & 22 & $76.0-81.0$ to 0 & $7.72-13.57$ & 8 \\
\hline & & McHugh and others (1993) & $25 \pm 1$ & $60.3-63.7$ to 0 & $6.17-7.48$ & 9 \\
\hline & & ND & $25 \pm 1$ & $77.2-79.0$ to 0 & $3.51-3.99$ & 10 \\
\hline & LM pectin & McHugh and others (1993) & $25 \pm 1$ & $77.6-80.4$ to 0 & $3.81-5.05$ & 11 \\
\hline & & McHugh and others (1993) & $25 \pm 1$ & $77.6-79.3$ to 0 & $3.43-3.86$ & 12 \\
\hline & & McHugh and others (1993) & ND & $72.0-77.1$ to 0 & $3.13-3.96$ & 13 \\
\hline & Sodium alginate & McHugh and others (1993) & $25 \pm 1$ & $63.5-67.1$ to 0 & $4.37-5.25$ & 14 \\
\hline Apricot & - & McHugh and others (1993) & $25 \pm 1$ & 80 to 0 & 4.29 & 7 \\
\hline \multirow[t]{2}{*}{ Banana } & - & Assis and Hotchkiss (2007) & ND & ND & $3.64-4.31$ & 15 \\
\hline & Pectin & ASTM E96 & 25 & ND & $1.90-3.03$ & 16 \\
\hline \multirow[t]{4}{*}{ Carrot } & $\begin{array}{l}\text { Chitosan, corn starch, } \\
\text { and gelatin }\end{array}$ & ASTM E96 & ND & ND & $3.94-9.81$ & 17 \\
\hline & $\mathrm{CMC}$ & ASTM E96 & $25 \pm 1$ & 83 to 0 & $2.18-3.27$ & 18 \\
\hline & Corn starch & ASTM E96 & $25 \pm 1$ & 83 to 0 & $1.91-4.62$ & 18 \\
\hline & Gelatin & ASTM E96 & $25 \pm 1$ & 83 to 0 & $2.16-3.83$ & 18 \\
\hline Cranberry & LM pectin & Gennadios and others (1994) & 25 & 100.0 to 50 & $2.85-3.05$ & 19 \\
\hline Guava & HPMC & McHugh and others (1993) & 25 & ND & $1.58-2.09$ & 20 \\
\hline Isotonic drink residue & - & ASTM E96 & 25 & 100 to 0 & $2.45-2.78$ & 21 \\
\hline \multirow[t]{2}{*}{ Mango } & - & McHugh and others (1993) & $25 \pm 1$ & ND & $1.67-2.66$ & 22 \\
\hline & - & McHugh and others (1993) & $27 \pm 3$ & ND to 50 & 8.88 & 23 \\
\hline \multirow[t]{7}{*}{ Papaya } & HM pectin & McHugh and others (1993) & $25 \pm 1$ & $77.5-80.2$ to 0 & $2.70-3.26$ & 24 \\
\hline & HPMC & McHugh and others (1993) & 25 & ND & $1.58-2.09$ & 25 \\
\hline & LM pectin & McHugh and others (1993) & $25 \pm 1$ & $79.3-80.1$ to 0 & $2.15-3.10$ & 24 \\
\hline & Soy protein & ASTM F1249 & $38 \pm 2$ & 90 to 0 & 7.52 & 26 \\
\hline & Starch & ASTM F1249 & $38 \pm 2$ & 90 to 0 & 8.45 & 26 \\
\hline & Starch and gelatin & ASTM F1249 & $38 \pm 2$ & 90 to 0 & $6.29-7.80$ & 26 \\
\hline & $\begin{array}{l}\text { Starch, soy protein, } \\
\text { and gelatin }\end{array}$ & ASTM F1249 & $38 \pm 2$ & 90 to 0 & $5.55-6.42$ & 26 \\
\hline Peach & - & McHugh and others (1993) & $25 \pm 1$ & 80 to 0 & 4.18 & 7 \\
\hline Pear & - & McHugh and others (1993) & $25 \pm 1$ & 84 to 0 & 7.77 & 7 \\
\hline Pomegranate & HM pectin & ASTM E96 & 24 & ND to $<1$ & $3.12-10.91$ & 27 \\
\hline Strawberry & HM pectin & McHugh and others (1993) & $25 \pm 1$ & $81.9-82.2$ to 0 & $0.61-0.92$ & 28 \\
\hline \multirow[t]{2}{*}{ Tomato } & HM pectin & McHugh and others (1993) & $25 \pm 1$ & $81.5-85.1$ to 0 & $2.11-2.68$ & 29 \\
\hline & & McHugh and others (1993) & $N^{c}$ & $80.1-81.9$ to 0 & $2.35-2.77$ & 30 \\
\hline \multirow[t]{3}{*}{ Wine grape } & LM pectin & $\begin{array}{c}\text { Gennadios and others (1994); } \\
\text { Park and Zhao (2006) }\end{array}$ & 25 & 100 to 50 & 2.62 & 31 \\
\hline & Sodium alginate & $\begin{array}{c}\text { Gennadios and others (1994); } \\
\text { Park and Zhao (2006) }\end{array}$ & 25 & 100 to 50 & 2.50 & 31 \\
\hline & Ticafilm ${ }^{\circledR}$ a & $\begin{array}{c}\text { Gennadios and others (1994); } \\
\text { Park and Zhao (2006) }\end{array}$ & 25 & 100 to 50 & 2.92 & 31 \\
\hline
\end{tabular}

RH, relative humidity; HM, high-methoxyl; ND, not disclosed; LM, low-methoxyl; CMC, carboxymethylcellulose; HPMC, hydroxypropyl methylcellulose.

${ }^{a}$ Ticafilm ${ }^{\circledR}$ is a mixture of sodium alginate, carrageenan, and cellulose gum.

Cited references: ${ }^{1}$ Espitia and others (2014a); ${ }^{2}$ Espitia and others (2014b); ${ }^{3}$ Farias and others (2012); ${ }^{4}$ Azeredo and others (2012a); ${ }^{5}$ Azeredo and others (2012b); ${ }^{6}$ Eça and others (2015); ${ }^{7}$ McHugh and others (1996); ${ }^{8}$ McHugh and Senesi (2000); ${ }^{9}$ Rojas-Graü and others (2006); ${ }^{10}$ Ravishankar and others (2009); ${ }^{11}$ Du and others (2008b); ${ }^{12}$ Du and others (2009a); ${ }^{13}$ Du and others (2011); ${ }^{14}$ Rojas-Graü and others (2007); ${ }^{15}$ Martelli and others (2015); ${ }^{16}$ Martelli and others (2013): ${ }_{i}^{17}$ Wang and others (2011 a); 18 Wang and others (2011 b); 19 Park and Zhao (2006); 20 Lorevice and others (2012); ${ }^{21}$ Andrade and others (2016); ${ }^{22}$ Azeredo and others (2009); ${ }^{23}$ Sothornvit and Rodsamran (2008); ${ }^{24}$ Otoni and others (2014); ${ }^{25}$ Lorevice and others (2014); ${ }^{26}$ Tulamandi and others (2016); ${ }^{27}$ Azeredo and others (2016); ${ }^{28}$ Peretto and others (2014): ${ }^{29}$ Du and others (2008a); ${ }^{30}$ Du and others (2009b); ${ }^{31}$ Deng and Zhao (2011).

gravimetrically. Although water vapor transmission rate, water va- polymers films, including HDPE, LDPE, and EVOH (0.00083, por permeation and WVP values can be obtained, the latter is by far 0.003 , and $0.010 \mathrm{~g} \mathrm{~mm} / \mathrm{m}^{2} / \mathrm{h} / \mathrm{kPa}$, respectively- measured at the most studied and reported parameter. WVP is affected by the $38{ }^{\circ} \mathrm{C}$ and with a $90 \%$ to $0 \% \mathrm{RH}$ gradient (McHugh and others mobility and free volume of the macromolecules as well as the in- 1996). Because the RH gradients between the 2 sides of films tegrity and hydrophilic-hydrophobic and crystalline-amorphous are the driving force for water vapor permeation, proper comratios of the films. Table 5 summarizes WVP of different edible parisons are allowed when different samples are exposed to the films based on fruits and vegetables.

As shown in Table 5 , the WVP of fruit and vegetable puree edible films ranged from 0.10 to $13.57 \mathrm{~g} \mathrm{~mm} / \mathrm{m}^{2} / \mathrm{h} / \mathrm{kPa}$. As expected, these values are much higher than the typical WVP of synthetic same RH conditions (Du and others 2009a; Otoni and others 2014). Nonetheless, this parameter has not always been considered (Table 5). We thus emphasize that every WVP comparison should take the RH gradients into account. 
Fruit and vegetable edible films...

Table 6-0xygen permeability $\left(\mathrm{O}_{2} \mathrm{P}\right)$ of edible films based on fruits and vegetables

\begin{tabular}{|c|c|c|c|c|c|c|}
\hline $\begin{array}{l}\text { Fruit/ } \\
\text { vegetable }\end{array}$ & Binding agent & Method & $\mathrm{T}\left({ }^{\circ} \mathrm{C}\right)$ & $\mathrm{RH}(\%)$ & $\begin{array}{c}\mathrm{O}_{2} \mathrm{P}\left(\mathrm{cm}^{3} \mu \mathrm{m} /\right. \\
\left.\mathrm{m}^{2} / \mathrm{d} / \mathrm{kPa}\right)\end{array}$ & Reference \\
\hline \multirow[t]{3}{*}{ Apple } & HM pectin & ASTM D3985 & 23 & $50 \pm 1$ & $22.6-38.1$ & Rojas-Graü and others (2006) \\
\hline & LM pectin & ASTM D3985 & 23 & $55 \pm 1$ & $63.0-83.6$ & Du and others (2008b) \\
\hline & Sodium alginate & ASTM D3985 & 23 & $50 \pm 1$ & $9.4-11.0$ & Rojas-Graü and others (2007) \\
\hline Banana & Pectin & ND & 25 & $50 \pm 1$ & $22.5-41.0$ & Sothornvit and Pitak (2007) \\
\hline \multirow[t]{2}{*}{ Carrot } & Chitosan, corn starch, and gelatin & ASTM D3985 & $23 \pm 1$ & $50 \pm 1$ & $8.8-19.7$ & Wang and others (2011a) \\
\hline & CMC, corn starch, and gelatin & ASTM D3985 & $23 \pm 1$ & $50 \pm 1$ & $11.7-12.5$ & Wang and others (201 1b) \\
\hline Mango & - & ND & $25 \pm 2$ & $55 \pm 5$ & 41.2 & Sothornvit and Rodsamran (2008) \\
\hline \multirow[t]{4}{*}{ Papaya } & Soy protein & ASTM D3985 & 23 & ND & 8.9 & Tulamandi and others (2016) \\
\hline & Starch & ASTM D3985 & 23 & ND & 8.7 & Tulamandi and others (2016) \\
\hline & Starch and gelatin & ASTM D3985 & 23 & ND & $7.5-8.2$ & Tulamandi and others (2016) \\
\hline & Starch, soy protein, and gelatin & ASTM D3985 & 23 & ND & $7.8-8.6$ & Tulamandi and others (2016) \\
\hline Peach & - & ASTM D3985 & 23 & 58 & 69.60 & McHugh and others (1996) \\
\hline
\end{tabular}

T, temperature; RH, relative humidity; HM, high-methoxyl; LM, low-methoxyl; ND, not disclosed; CMC, carboxymethylcellulose.

Strategies to improve the water barrier properties of edible films based on fruits and vegetables include the formulation of nanocomposites (Azeredo and others 2012b). The WVP of mango puree edible films was reduced from 2.66 to $1.67 \mathrm{~g} \mathrm{~mm} / \mathrm{m}^{2} / \mathrm{h} / \mathrm{kPa}$ when $36 \%$ (wt.) of cellulose nanofiber (CNF) were added (Azeredo and others 2009). Similarly, the WVP of acerola puree edible films was decreased from 1.07 to 0.73 or $0.68 \mathrm{~g} \mathrm{~mm} / \mathrm{m}^{2} / \mathrm{h} / \mathrm{kPa}$ upon the addition of $10 \%$ (wt.) of CNC or MMT nanoclay (Azeredo and others 2012a). The addition of chitosan nanoparticles reduced the WVP of guava puree edible films from 2.09 to $1.58 \mathrm{~g} \mathrm{~mm} / \mathrm{m}^{2} / \mathrm{h} / \mathrm{kPa}$ (Lorevice and others 2012) as well as that of banana puree edible films from 3.03 to $1.90 \mathrm{~g} \mathrm{~mm} / \mathrm{m}^{2} / \mathrm{h} / \mathrm{kPa}$ (Martelli and others 2013). These outcomes have been attributed to the increased tortuosity of the diffusive pathway, making water vapor diffusion slower (Azeredo and others 2009; Azeredo and others 2012a). Apple skin polyphenols were assumed to form hydrogen and covalent bonds with pectin and/or apple puree polar groups, resulting in less hydrophilic materials that, consequently, were less permeable to water vapor (Du and others 2011).

The aforementioned strategies involve the addition of hydrophilic fillers, but the incorporation of hydrophobic additives, lipids, for instance, as an approach for obtaining improved water barrier properties has been suggested by McHugh and others (1996), and corroborated in later investigations on the addition of vegetable oils, fatty acids, and beeswax into apple puree edible films (McHugh and Senesi 2000); oregano, lemongrass, and cinnamon essential oils into apple puree edible films (Rojas-Graü and others 2006); oregano essential oil, carvacrol, and cinnamaldehyde into carrot puree edible films (Wang and others 2011a); cinnamaldehyde nanoemulsions into papaya puree edible films (Otoni and others 2014); carvacrol and methyl cinnamate into strawberry puree edible films (Peretto and others 2014). Carvacrol improved water barrier of bench-cast edible films from apple (Du and others 2008b) and tomato (Du and others 2008a) purees, but the same behavior was not observed in its continuous-cast counterparts, probably because of the increased carvacrol evaporation resulting from higher drying temperatures.

Barrier to oxygen. It is highly desirable that food exposure to oxygen is limited since it can lead to oxidation as well as sensory (odor, color, flavor, and texture) changes and nutritional losses (Sothornvit and Pitak 2007). Because hydrocolloids (both those present in fruits and vegetables and those added to the FFFs as binding agents) are usually mostly polar in nature, the resulting films are expected to be good barriers to nonpolar gasses, including oxygen (Wang and others $2011 \mathrm{~b}$ ). The $\mathrm{O}_{2} \mathrm{P}$ values of edible films based on fruits and vegetables are presented in Table 6 .
Edible films based on fruits and vegetables showed $\mathrm{O}_{2} \mathrm{P}$ values ranging from 7.5 (papaya puree films) to $83.6 \mathrm{~cm}^{3} \mu \mathrm{m} / \mathrm{m}^{2} / \mathrm{d} / \mathrm{kPa}$ (apple puree films), values which are remarkably smaller than conventional films from HDPE $\left(427 \mathrm{~cm}^{3} \mu \mathrm{m} / \mathrm{m}^{2} / \mathrm{d} / \mathrm{kPa}\right)$ and LDPE $\left(1870 \mathrm{~cm}^{3} \mu \mathrm{m} / \mathrm{m}^{2} / \mathrm{d} / \mathrm{kPa}\right)$-measured at $23{ }^{\circ} \mathrm{C}$ and $50 \%$ RH (McHugh and others 1996). The $\mathrm{O}_{2} \mathrm{P}$ of peach puree edible films were reduced from 69.6 to $0.35 \mathrm{~cm}^{3} \mu \mathrm{m} / \mathrm{m}^{2} / \mathrm{d} / \mathrm{kPa}$ when the environment $\mathrm{RH}$ was changed from $58 \%$ to $38 \%$ (McHugh and others 1996), due to the plasticizing effects of water. Essential oils and oil compounds have also been reported to enhance the oxygen barrier of edible films based on fruits and vegetables, such as apple puree films added by carvacrol (Du and others 2008b), citral, and lemongrass essential oil (Rojas-Graü and others 2007). The opposite behavior has also been reported, though (RojasGraï and others 2007; Wang and others 2011a). Regardless of the incorporation of active compounds, edible films based on fruits and vegetables were shown to be good barriers to oxygen, being promising not only in extending stability of foods highly susceptible to oxidation (McHugh and others 1996), but also in retarding respiration rates of fruits and vegetables (McHugh and Senesi 2000).

\section{Thermal properties}

Polymer chain mobility determines the physical characteristics of the final film, which may behave as a hard, brittle or a tough, rubbery plastic or even as a viscous fluid instead. Chain mobility is due to movement of atoms, and is expected to be increased with temperature (Lorevice and others 2012). Therefore, the thermal characteristics of edible films based on fruits and vegetables are of utmost importance, especially of those intended for packaging applications.

The $T_{g}$ of mango puree films, as indicated by differential scanning calorimetry, varied from -10.63 to $-5.88^{\circ} \mathrm{C}$ as a result of the addition of increasing CNF contents (Azeredo and others 2009). These low $T_{g}$ values have been ascribed to the plasticizing effect of short-chain sugars present in mango puree. Slightly lower $T_{g}$ values, about $-17^{\circ} \mathrm{C}$, were reported for films from mango and acerola purees added by starch (Souza and others 2012), and even lower $T_{g}$ values, approximately $-44^{\circ} \mathrm{C}$, were found for pectin-added banana puree films (Martelli and others 2013). While those low $T_{g}$ values may be undesirable from the chemical stability standpoint (since high chain mobility is expected to lead to high reactivity), they provide films with good flexibility even under refrigeration (eventually even at freezing temperatures, depending on how low is the $T_{g}$ of the film), which is interesting for food packaging applications (Azeredo and others 2009). Remarkably different $T_{g}$ 
values have been observed for edible films based on guava $\left(189^{\circ} \mathrm{C}\right)$ and papaya $\left(232^{\circ} \mathrm{C}\right)$ purees added by HPMC (Lorevice and others 2012, 2014).

Edible films based on fruits and vegetables may be produced in industrial scale in order to decrease processing time, increase yield, and reduce production cost, but temperatures lower that their degradation temperatures should be used. Thermogravimetry has shown that pectin-added banana puree edible films degrade in 3 main stages within a nitrogen atmosphere (Martelli and others 2013). The 1 st stage, occurring at temperatures lower than $100^{\circ} \mathrm{C}$, was attributed to the desorption of moisture physically adsorbed in the film. The onset of the 2nd mass loss stage was at approximately $130{ }^{\circ} \mathrm{C}$, where short-chain sugars (fructose, sucrose, and glucose), starch and proteins began to degrade irreversibly. The 3rd stage occurred between 230 and $400{ }^{\circ} \mathrm{C}$ and was assigned to the thermal deterioration of more complex compounds such as lignin, hemicelluloses, and cellulose. For those films, processing at temperatures above $130{ }^{\circ} \mathrm{C}$ is not recommended (Martelli and others 2013).

Pectin- and thyme essential oil-added açaí puree edible films showed an additional mass loss stage in an inert atmosphere (Espitia and others 2014a, 2014b). Similar to banana films, a 1st stage (50 to $100{ }^{\circ} \mathrm{C}$ ) was assigned to water evaporation and thyme essential oil volatilization. Then, pectin began to degrade at $150^{\circ} \mathrm{C}$ with a maximum rate at $226^{\circ} \mathrm{C}$. The onsets of the subsequent mass loss stages were $300{ }^{\circ} \mathrm{C}$ (decomposition of glycerol) and $400{ }^{\circ} \mathrm{C}$ (decomposition of the lignocellulosic fibers from apple skin and açaí). Compared to the previously presented values, films made up of guava puree added by HPMC under a synthetic air atmosphere presented a wider processability window because the degradation temperature was around $190{ }^{\circ} \mathrm{C}$ (Lorevice and others 2012).

Although the scaled-up production of edible films based on fruits and vegetables by continuous casting involves heating, the thermal behavior of such materials has not been considered in most studies. A comprehensive characterization of the thermal properties of edible films based on fruits and vegetables is highly recommended in future investigations in order to determine their processability window as well as to evaluate the feasibility of using them in real industrial operations.

\section{Nutritional properties}

Among the exclusive characteristics of edible films based on fruits and vegetables, their nutritional and health-promoting functional properties should be focused. Just $1 \mathrm{~g}$ of starch-added acerola films presented up to $3761.84 \mathrm{mg}$ of vitamin $\mathrm{C}$ and up to about $5000 \mathrm{mg}$ of $\beta$-carotene, representing 3.8 times and 56 times the recommended daily intakes for those nutrients (Farias and others 2012). Acerola edible films were then shown to be an additional source of vitamin $\mathrm{C}$ and $\beta$-carotene (Farias and others 2012).

Dantas and others (2015) monitored the total phenolic content (TPC) in films mango, acerola, and red monbin purees throughout a 40-d storage of palm oil. The edible films allowed the gradual migration of phenolics to palm oil, which was corroborated by a $50 \%$ decrease in the peroxide index of the packaged product in comparison to control starch films. The release of phenolics from grape pomace-based films added with low-methoxyl pectin, alginate, and Ticafilm ${ }^{\circledR}$ to deionized water were shown to be $96.6 \%$, 93.8\%, and $80.5 \%$, respectively (Deng and Zhao 2011), indicating that the interaction between active compounds and film-forming biomacromolecules play a significant role on their release kinetics. The contents of phenolics (TPC; 43.41 to $178.53 \mathrm{mg} / \mathrm{g}$ ), flavonoid (TFC; 23.24 to $62.54 \mathrm{mg} / \mathrm{g}$ ), and carotenoids (TCC; 21.15 to $48.10 \mu \mathrm{g} / \mathrm{g}$ ) were found to be proportional to the concentrations of mango puree and yerba mate extract in the FFF (Reis and others 2015). These films were used to pack palm oil for $90 \mathrm{~d}$, during which time the TCC of palm oil decreased while the peroxide index increased, suggesting oxidation. The oxidation levels were found to be lower for films comprising higher fruit and vegetable loads, yerba mate extract particularly.

Films based on mango and acerola purees also showed concentration-dependent TPC (89.17 to $168.80 \mathrm{mg} / \mathrm{g})$, TCC (31.15 to $70.56 \mu \mathrm{g} / \mathrm{g}$ ), vitamin C content (65.4 to approximately $600 \mu \mathrm{g} / \mathrm{g}$ ), and radical-scavenging activity, as indicated by the lower peroxide index and contents of hexanal and conjugated dienes (oxidation products) observed for soybean oil packaged in films comprising higher puree ratios (Souza and others 2011). A remarkable antioxidant activity has also been presented by films from grape pomace extract due to its TFC (Hayashi and others 2006), but spinach extract did not show the same activity, probably because of its chlorophyll content, which may have acted as a pro-oxidant.

Because the nutritional and functional properties of naturally occurring compounds in edible films based on fruits and vegetables stand out as unique characteristics distinguishing them from conventional polymer films, these properties are worth of deeper investigation in future studies.

\section{Antimicrobial properties}

As previously discussed, edible films based on fruits and vegetables can act as carriers of active compounds, including antimicrobials, which may either be immobilized into the film matrix and play their role upon contact with food surface or be slowly released into foodstuffs. Comparing the antimicrobial activity of the FFF to that of the dried film is a useful tool for evaluating the effect of the drying procedure on the antimicrobial performance of the resulting material.

Rojas-Graï and others (2006) determined the bactericidal efficiency against Escherichia coli O157:H7 of apple puree-based FFFs incorporated with oregano $(0.1 \% \mathrm{wt}$.), lemongrass $(0.5 \% \mathrm{wt}$.) or cinnamon $\left(0.5 \%\right.$ wt.) essential oils and reported $\mathrm{BA}_{50}$ values (that is, the percentage of antimicrobial compound that killed $50 \%$ of the tested bacteria under the tested conditions) of $0.034,>0.34$, and 0.28 , respectively, after incubation for $3 \mathrm{~min}$ at $21^{\circ} \mathrm{C}$. Those values were reduced to $0.024,0.12$, and 0.078 in the following $27 \mathrm{~min}$, indicating that oregano essential oil showed the highest bactericidal activity even at the lowest concentration, and that $30 \mathrm{~min}$ were required for cinnamon essential oil to be effective. The dried films were also tested against E. coli O157:H7 and, likewise, oregano essential oil showed the best outcome as indicated by the largest inhibition zone around a film disk (Rojas-Graü and others 2006). In another study, Rojas-Graü and others (2007) incorporated apple puree edible films with the same essential oils or with their major antimicrobial compounds, namely, carvacrol, citral, and cinnamaldehyde, respectively. As expected, the inhibition zones of E. coli O157:H7 created around films incorporated with the antimicrobial compounds were greater than those around films added with the original essential oils, carvacrol having the most pronounced antimicrobial effect. In contrast, the inhibition zones of Staphylococcus aureus and E. coli were larger for carrot puree edible films with cinnamaldehyde than those added with carvacrol (Wang and others 2011a). Carvacrol was also added to apple and tomato puree edible films, which were effective in inhibiting the growth of E. coli O157:H7, with increasing carvacrol contents 
resulting in greater antimicrobial efficiencies ( $\mathrm{Du}$ and others 2008b, 2009b).

Apple puree edible films added by apple skin polyphenols were demonstrated by $\mathrm{Du}$ and others (2011) to be highly effective against Listeria monocytogenes, the minimum inhibitory concentration being 1.5\%, while the films inhibited neither E. coli O157:H7 nor Salmonella enterica. Açá edible films incorporated with apple skin polyphenols and thyme essential oil were effective in inhibiting the growth of $L$. monocytogenes, the antilisterial activity of the latter being greater than that of the former (Espitia and others 2014b).

Otoni and others (2014) incorporated papaya puree films with cinnamaldehyde nanoemulsions of different droplet sizes. While all films were able to inhibit E. coli, S. enterica, L. monocytogenes and $S$. aureus, greater antimicrobial efficiencies were obtained for nanoemulsions of smaller droplets, allowing one to boost the antibacterial activity of edible films based on fruits and vegetables containing low preservative contents by simply breaking up their 2nd phases.

The antimicrobial efficiency of edible films may be evaluated by different methodologies, including the overlay test/direct contact with the growth medium (laboratory media or real foods) and the vapor phase method, the latter being suitable to volatile compounds as well as applications in which there is little or no contact between food and packaging (Du and others 2009a). Apple puree edible films have been incorporated with different concentrations ( $0.5 \%$ to $3.0 \% \mathrm{wt}$.) of cinnamon, allspice, and clove bud essential oils, and had their antimicrobial activities against $E$. coli $\mathrm{O} 157: \mathrm{H} 7$, $S$. enterica, and L. monocytogenes evaluated by both overlay and vapor phase tests ( $\mathrm{Du}$ and others 2009a). Regardless of the test method, none of the essential oils was able to inhibit microbial growth at $0.5 \%$, whereas all of them did so at $3.0 \%$. As for the intermediate concentrations, remarkable differences were observed between the 2 methods, indicating that the vapor phases of such essential oils lead to greater inhibitory effects. Similar dose- and phase-dependent outcome has been obtained for tomato puree films incorporated with 0.5 to $3.0 \%$ (wt.) of oregano, allspice, and garlic essential oils (Du and others 2009b).

Antimicrobial edible films based on fruits and vegetables have also been tested in real food. Apple, carrot, and hibiscus films incorporated with carvacrol and cinnamaldehyde were found to effectively control the growth of L. monocytogenes for $7 \mathrm{~d}$ in sliced ham and bologna, with carvacrol and apple puree showing the best antilisterial activity (Ravishankar and others 2012). Apple, carrot, and hibiscus films added by carvacrol and cinnamaldehyde also protected lettuces and spinaches from Salmonella Newport development during a week (Zhu and others 2014).

\section{Potential Applications}

Although edible films based on fruits and vegetables feature the unique characteristics previously discussed in this text, they may be used simply as a passive layer, that is, with no active role, but with the advantage of partially replacing the nonrenewable materials traditionally used for this purpose, reducing the concern with disposal when compared to nonbiodegradable materials as well as improving recyclability as a result of the decreased requirements for coating, coextrusion, and lamination (McHugh and others 1996; Farias and others 2012).

Because of their high polarity, most edible films are good barriers to gasses but poor barrier to moisture (Azeredo and others 2012a). As a result, these semipermeable barriers may create modified atmosphere packaging systems when applied to fruits and vegetables, whose respiratory gasses (oxygen and carbon dioxide) can be exchanged in a controlled fashion and lead to slower metabolism and ethylene production (Sothornvit and Rodsamran 2010b).

Active packaging is among the most promising applications of edible films based on fruits and vegetables. This approach is of interest because the direct addition of antimicrobial compounds or other additives into food formulations requires much higher additive contents, which in turn may lead to undesirable sensory changes (Espitia and others 2014b). Active films represent a promising way to slowly release functional additives to food surface, which may act as additional hurdles against food spoilage. The possibility of acting as carriers for a wide range of food additivesincluding vitamins, antioxidants, minerals, colorants, aromas, and antimicrobial compounds-makes this class of edible films promising as active packaging. Edible films based on fruits and vegetables added with active components have been shown to play antioxidant and/or antimicrobial roles, thus extending the shelf-lives of organic leafy greens (Zhu and others 2014), soybean oil (Hayashi and others 2006), palm oil (Souza and others 2011; Dantas and others 2015; Reis and others 2015), chicken breasts (Ravishankar and others 2009), strawberry (Peretto and others 2014), ham and bologna (Ravishankar and others 2012), besides successfully maintaining the quality of sugar (Sothornvit and Pitak 2007), mango (Sothornvit and Rodsarman 2008), and apple (McHugh and Senesi 2000) throughout storage. Nevertheless, the active properties of these materials deserve further exploitation.

Ultimately, fruits and vegetables can be used to produce wraps, innovatively commercialized in the USA applying ARS patents (McHugh and others 2006, 2012) and their technical support, and leathers or pestils. Fruit and vegetable leathers are cohesive layers obtained by water removal from wet fruit or vegetable purees. They are expected to be thicker edible films with a leathery, chewy consistency. Similar to films, fruit and vegetable leathers are much more stable to deterioration than the plant materials from which they are derived due to their reduced moisture content and water activity. Leathers obtained from apple (Valenzuela and Aguilera 2015), grape juice (Kaya and Maskan 2003), kiwi (Concha-Meyer and others 2016), papaya (Addai and others 2016), pear (Huang and Hsieh 2005), and strawberry (Concha-Meyer and others 2016) are among the fruit and vegetable leathers reported in the literature.

The previously discussed potential applications of edible films based on fruits and vegetables, as well as their basic components and remarkable characteristics, are illustrated in Figure 4.

\section{Concluding Remarks and Future Perspectives}

As pointed out previously, some properties of edible films, particularly those obtained from fruit and vegetable purees, still need some improvement, such as tensile and barrier properties, and water resistance. Overall, edible films based on fruits and vegetables are soluble in water to high extents (Figure 5).

This high water solubility may be desirable for some applications, such as when the films are supposed to be consumed as snacks or to be melted/dissolved upon cooking or contact with hot food components. When this is the case, water solubility avoids sensory changes (Farias and others 2012). On the other hand, a poor water resistance may be a problem when the film is supposed to act as a barrier for food protection, but water-soluble films are still suitable for fatty foods (Liu and others 2017).

Concerning mechanical and barrier properties, several approaches may be useful in order to enhance those properties, such as chemical modifications, incorporation of nanoreinforcements, 


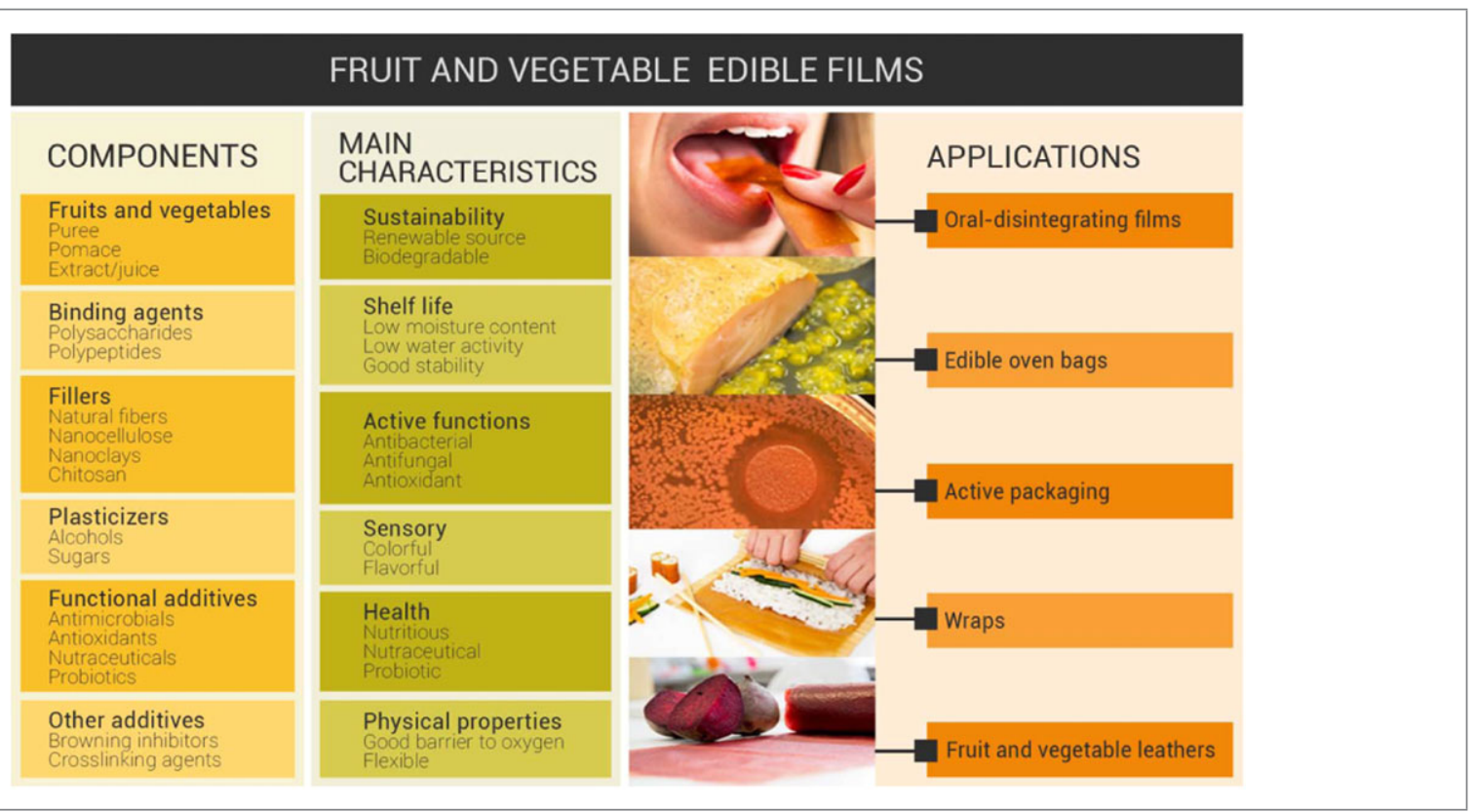

Figure 4-Essential film-forming components as well as common characteristics and potential applications of edible films based on fruits and vegetables.
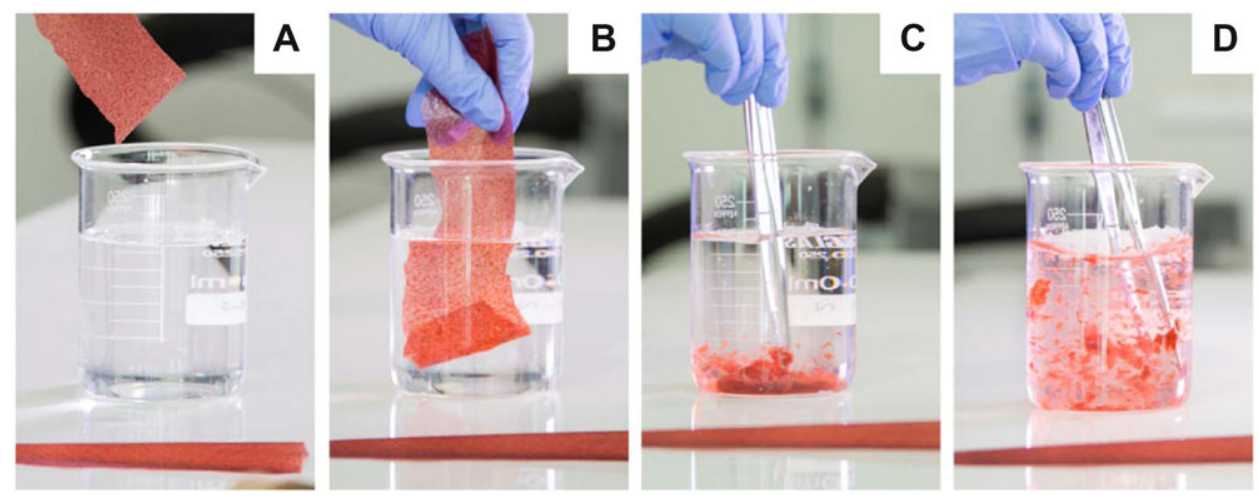

Figure 5-Solubilization of a beetroot puree edible film in water. Once dipped (B), stages C and D took approximately 40 and 100 s, respectively. Complete solubilization in water was reached after about $5 \mathrm{~min}$ of immersion with gentle stirring.

or crosslinking. However, any modification or incorporation to the materials must be considered in order to preserve the edibility, making toxicity tests essential for the continuous development of edible films based on fruits and vegetables with suitable physical properties. In case the required physical properties are not met even after these modifications, edible films are still suitable as snacks (Azeredo and others 2012b).

Another obstacle to the worldwide use of biodegradable and edible packaging materials is their relatively high cost, thus actual applications are still limited to special niches like those with environmental considerations (Guilbert and Gontard 2005). In this context, the presence of fruit and vegetable purees in edible films and coatings make them more attractive to consumers due to the additional sensory and nutritional appeal imparted by the purees. Films and coatings containing those purees are not merely barriers to the food, but have their own market appeal. Additionally, the use of inexpensive, underutilized food processing by-products is a promising strategy for producing cheaper films that still present the sensory and physicochemical characteristics that distinguish them from films made up of conventional polymers.

Finally, edible films based on fruits and vegetables with novel health-promoting functionalities may also be developed, such as probiotic or prebiotic films, increasing their market appeal as healthy food components with desirable sensory properties (Espitia and others 2016). In a world increasingly focused on health aspects, those kinds of applications are expected to be continuously exploited.

\section{Acknowledgments}

The authors thank the financial support provided by São Paulo Research Foundation (FAPESP, grant \#2014/23098-9), Natl. Council for Scientific and Technological Development (CNPq, grant \#303.796/2014-6), Ministry of Science, Technology, and Innovation (MCTI/SisNANO, award \#402.287/2013-4), and Coordination for the Improvement of Higher Education Personnel (CAPES, grant \#33001014005D-6). The technical com- 
ments of Dr. Francys Moreira as well as the artwork production by Leonardo Chaves (Figure 2), Luiza Stalder (Figure 3), Renan Alcantara (1st and 4th pictures on Figures 4), Vanessa Lopez (2nd picture on Figure 4), Peggy Greb - USDA/ARS (3rd picture on Figure 4), and Samuel Vasconcelos (Figure 5 and 5 th picture on Figure 4) are also acknowledged.

\section{Author Contributions}

CG Otoni and LHC Mattoso conceived and designed the study. CG Otoni, MV Lorevice, and MR de Moura researched the literature. CG Otoni and MV Lorevice compiled data into tables. HMC Azeredo and MV Lorevice created schemes and figures. CG Otoni and HMC Azeredo drafted the manuscript. HMC Azeredo, RJ Avena-Bustillos, LHC Mattoso, and TH McHugh revised the manuscript critically.

$\begin{array}{ll}\text { Nomenclature } \\ \text { CMC } & \text { carboxymethylcellulose } \\ \text { CNC } & \text { cellulose nanocrystal } \\ \text { CNF } & \text { cellulose nanofiber } \\ \text { EVOH } & \text { ethylene-vinyl alcohol copolymer } \\ \text { FFF } & \text { film-forming formulation } \\ \text { GRAS } & \text { generally regarded as safe } \\ \text { HDPE } & \text { high-density polyethylene } \\ \text { HM } & \text { high-methoxyl } \\ \text { HPMC } & \text { hydroxypropyl methylcellulose } \\ \text { IR } & \text { infrared } \\ \text { LDPE } & \text { low-density polyethylene } \\ \text { LM } & \text { low-methoxyl } \\ \text { MC } & \text { methylcellulose } \\ \text { MCC } & \text { microcrystalline cellulose } \\ \text { MMT } & \text { montmorillonite } \\ \text { ND } & \text { not disclosed } \\ \text { O } & \text { oxygen permeability } \\ \text { PC } & \text { polycarbonate } \\ \text { PCL } & \text { poly(E-caprolactone) } \\ \text { PE } & \text { polyethylene } \\ \text { PET } & \text { poly(ethylene terephthalate) } \\ \text { PLA } & \text { poly(lactic acid) } \\ \text { PMMA } & \text { poly(methyl methacrylate) } \\ \text { PP } & \text { polypropylene } \\ \text { PS } & \text { polystyrene } \\ \text { PTFE } & \text { polytetrafluoroethylene } \\ \text { PVC } & \text { polyvinylchloride } \\ \text { PVDC } & \text { poly(vinylidene chloride) } \\ \text { PVOH } & \text { polyvinyl alcohol } \\ \text { RH } & \text { relative humidity } \\ \text { TCC } & \text { total carotenoid content } \\ \text { TFC } & \text { total flavonoid content } \\ T_{g} & \text { glass transition temperature } \\ \text { TPC } & \text { total phenolic content } \\ \text { TPS } & \text { thermoplastic starch } \\ \text { WVP } & \text { water vapor permeability } \\ & \end{array}$

\section{References}

Addai ZR, Abdullah A, Mutalib SA, Musa KH. 2016. Evaluation of fruit leather made from two cultivars of papaya. Ital J Food Sci 28(1):73-82. https://doi.org/10.14674/1120-1770\%2FIJFS.V460

Amaral DP, Andrade K, Barbosa F, Carvalho CWP, Takeiti CY, Ascheri JLR, Fakhouri FM. 2010. Thermal analysis and mechanical properties of cassava starch edible films added of barbados cherry. $43^{\text {rd }}$ IUPAC World
Polymer Congress 43:F19-P82; Glasgow, United Kingdom; 11-16 July 2010. London, United Kingdom: Royal Society of Chemistry.

Amorati R, Foti MC, Valgimigli L. 2013. Antioxidant activity of essential oils J Agric Food Chem 61(46):10835-47. https://doi.org/10.1021/jf403496k.

Andrade RD, Skurtys O, Osorio FA. 2012. Atomizing spray systems for application of edible coatings. Compr Rev Food Sci Food Saf 11(3): 323-37. https://doi.org/10.1111/j.1541-4337.2012.00186.x.

Andrade RMS, Ferreira MSL, Gonçalves ECBA. 2016. Development and characterization of edible films based on fruit and vegetable residues. J Food Sci 81(2):E412-18. https://doi.org/10.1111/1750-3841.13192

Assis OBG, Hotchkiss JH. 2007. Surface hydrophobic modification of chitosan thin-films by HMDS plasma deposition: Effects on water vapor, $\mathrm{CO}_{2}$ and $\mathrm{O}_{2}$ permeabilities. Packag Technol Sci 20(4):293-7. https://doi. org/10.1002/pts.766.

ASTM. 2015a. ASTM D1922. In: Standard test method for propagation tear resistance of plastic film and thin sheeting by pendulum method. West Conshohocken, PA: ASTM Intl. https://doi.org/10.1520/D1922-15.

ASTM. 2015b. ASTM F88 / F88M-15. In: Standard test method for seal strength of flexible barrier materials. West Conshohocken, PA: ASTM Intl. https://doi.org/10.1520/F0088_F0088M-15.

ASTM. 2016. ASTM F1306. In: Standard test method for slow rate penetration resistance of flexible barrier films and laminates. West Conshohocken, PA: ASTM Intl. https://doi.org/10.1520/F1306-16.

Atarés L, Chiralt A. 2016. Essential oils as additives in biodegradable films and coatings for active food packaging. Trends Food Sci Technol 48:5162. https://doi.org/10.1016/j.tifs.2015.12.001

Azeredo HMC, Mattoso LHC, Wood D, Williams TG, Avena-Bustillos RJ, McHugh TH. 2009. Nanocomposite edible films from mango puree reinforced with cellulose nanofibers. J Food Sci 74(5):N31-N35. https:// doi.org/10.1111/j.1750-3841.2009.01186.x.

Azeredo HMC, Miranda KWE, Ribeiro HL, Rosa MF, Nascimento DM. 2012a. Nanoreinforced alginate-acerola puree coatings on acerola fruits. $J$ Food Eng 113(4):505-10. https://doi.org/10.1016/j.jfoodeng.2012.08.006.

Azeredo HMC, Miranda KWE, Rosa MF, Nascimento DM, de Moura MR 2012b. Edible films from alginate-acerola puree reinforced with cellulose whiskers. LWT-Food Sci Technol 46(1):294-7. https://doi.org/10.1016/ j.lwt.2011.09.016.

Azeredo HMC, Morrugares-Carmona R, Wellner N, Cross K, Bajka B, Waldron KW. 2016. Development of pectin films with pomegranate juice and citric acid. Food Chem 198:101-6. https://doi.org/10.1016/ j.foodchem.2015.10.117.

Azeredo HMC, Rosa MF, Mattoso LHC. 2017. Nanocellulose in bio-based food packaging applications. Ind Crops Prod. in press. https://doi.org/10. 1016/j.indcrop.2016.03.013.

Babu RP, O'Connor K, Seeram R. 2013. Current progress on bio-based polymers and their future trends. Prog Biomater 2:8. https://doi.org/10. 1186/2194-0517-2-8.

Bastarrachea L, Dhawan S, Sablani SS. 2011. Engineering properties of polymeric-based antimicrobial films for food packaging: a review. Food Eng Rev 3(2):79-93. https://doi.org/10.1007/s12393-011-9034-8.

Benbettaïeb N, Gay J-P, Karbowiak T, Debeaufort F. 2016. Tuning the functional properties of polysaccharide-protein bio-based edible films by chemical, enzymatic, and physical cross-linking. Compr Rev Food Sci Food Saf 15(4):739-52. https://doi.org/10.1111/1541-4337.12210.

Cagri A, Ustunol Z, Ryser ET. 2004. Antimicrobial edible films and coatings. J Food Prot 67(4):833-48.

Concha-Meyer AA, D'Ignoti V, Saez B, Diaz RI, Torres CA. 2016. Effect of storage on the physico-chemical and antioxidant properties of strawberry and kiwi leathers. J Food Sci 81(3):C569-77. https://doi.org/10.1111/ 1750-3841.13214.

Dantas EA, Costa SS, Cruz LS, Bramont WB, Costa AS, Padilha FF, Druzian JI, Machado BAS. 2015. Caracterização e avaliação das propriedades antioxidantes de filmes biodegradáveis incorporados com polpas de frutas tropicais. Cienc Rural 45(1):142-8. https://doi.org/10.1590/0103$8478 \mathrm{cr} 20131458$.

Deng Q, Zhao Y. 2011. Physicochemical, nutritional, and antimicrobial properties of wine grape (cv. Merlot) pomace extract-based films. J Food Sci 76(3):E309-17. https://doi.org/10.1111/j.1750-3841.2011.02090.x.

Du W-X, Avena-Bustillos RJ, Woods R, Breksa AP, McHugh TH, Friedman M, Levin CE, Mandrell R. 2012. Sensory evaluation of baked chicken wrapped with antimicrobial apple and tomato edible films formulated with cinnamaldehyde and carvacrol. J Agric Food Chem 60(32):7799-804. https://doi.org/10.1021/jf301281a. 
Du WX, Olsen CW, Avena-Bustillos RJ, Friedman M, McHugh TH. 2011. Physical and antibacterial properties of edible films formulated with apple skin polyphenols. J Food Sci 76(2):M149-55. https://doi.org/10.1111/ j.1750-3841.2010.02012.x.

Du WX, Olsen CW, Avena-Bustillos RJ, McHugh TH, Levin CE, Friedman M. 2009a. Effects of allspice, cinnamon, and clove bud essential oils in edible apple films on physical properties and antimicrobial activities. J Food Sci 74(7):M372-8. https://doi.org/10.1111/j.1750-3841.2009. $\underline{01282 . \mathrm{x}}$

Du WX, Olsen CW, Avena-Bustillos RJ, McHugh TH, Levin CE, Friedman M. 2008a. Antibacterial activity against E. coli O157:H7, physica properties, and storage stability of novel carvacrol-containing edible tomato films. J Food Sci 73(7)M378-83. https://doi.org/10.1111/j.1750-3841. 2008.00892.x

Du WX, Olsen CW, Avena-Bustillos RJ, McHugh TH, Levin CE, Friedman M. 2008b. Storage stability and antibacterial activity against Escherichia coli O157:H7 of carvacrol in edible apple films made by two different casting methods. J Agric Food Chem 56(9):3082-8. https://doi. org $/ 10.1021 / \mathrm{jf7} 03629 \mathrm{~s}$.

Du WX, Olsen CW, Avena-Bustillos RJ, McHugh TH, Levin CE, Mandrel R, Friedman M. 2009b. Antibacterial effects of allspice, garlic, and oregano essential oils in tomato films determined by overlay and vapor-phase methods. J Food Sci 74(7)M390-7. https://doi.org/10.1111/j.1750-3841. 2009.01289.x.

Eça KS, Machado MTC, Hubinger MD, Menegalli FC. 2015. Development of active films from pectin and fruit extracts: Light protection, antioxidant capacity, and compounds stability. J Food Sci 80(11):C2389-96. https://doi. org/10.1111/1750-3841.13074.

Espitia PJP, Avena-Bustillos RJ, Du W-X, Chiou B-S, Williams TG, Wood D, McHugh TH, Soares NFF. 2014a. Physical and antibacterial properties of açaí edible films formulated with thyme essential oil and apple skin polyphenols. J Food Sci 79(5):M903-10. https://doi.org/10.1111/17503841.12432

Espitia PJP, Avena-Bustillos RJ, Du W-X, Teófilo RF, Soares NFF, McHugh TH. 2014b. Optimal antimicrobial formulation and physical-mechanical properties of edible films based on açaí and pectin for food preservation. Food Packag Shelf Life 2(1):38-49. https://doi.org/10. 1016/j.fpsl.2014.06.002.

Espitia PJP, Batista RA, Azeredo HMC, Otoni CG. 2016. Probiotics and their potential applications in active edible films and coatings. Food Res Int 90:42-52. https://doi.org/10.1016/j.foodres.2016.10.026.

Espitia PJP, Du W-X, Avena-Bustillos RJ, Soares NFF, McHugh TH. 2014. Edible films from pectin: physical-mechanical and antimicrobial properties—a review. Food Hydrocolloids 35:287-96. https://doi.org/10. 1016/j.foodhyd.2013.06.005.

Farias MG, Fakhouri FM, de Carvalho CWP, Ascheri JLR. 2012.

Physicochemical characterization of edible starch films with barbados cherry (Malphigia emarginata D.C.). Quim Nova 35(3):546-52. https://doi.org/10. 1590/S0100-40422012000300020

Friedman M, Levin CE, Avena-Bustillos RJ, Olsen CW, McHugh TH 2007. AGFD 69-stability of the plant antimicrobial carvacrol in edible tomato/pectin puree films. Abstracts of Papers of the $234^{\text {th }}$ ACS National Meeting; Boston, MA; 19-23 August 3007. Washington, DC: American Chemical Society.

Gardner DJ, Oporto GS, Mills R, Samir MASA. 2008. Adhesion and surface issues in cellulose and nanocellulose. J Adhes Sci Technol 22(5-6): 545-567. https://doi.org/10.1163/156856108×295509.

Gennadios A, Weller CL, Gooding CH. 1994. Measurement errors in water-vapor permeability of highly permeable, hydrophilic edible films. J Food Eng 21(4):395-409. https://doi.org/10.1016/0260-8774(94)90062-0. Gross RA, Kalra B. 2002. Biodegradable polymers for the environment. Science 297(5582):803-7. https://doi.org/10.1126/science.297.5582.803. Guilbert S, Gontard N. 2005. Agro-polymers for edible and biodegradable films: Review of agricultural polymeric materials, physical and mechanical characteristics. In: Han JH, editor. Innovations in Food Packaging. London, United Kingdom: Academic Press. p 263-76. https://doi.org/10.1016/ B978-012311632-1/50048-6

Han JH, Aristippos G. 2005. Edible films and coatings: A review. In: Han $\mathrm{JH}$, editor. Innovations in Food Packaging. London, United Kingdom: Academic Press. p 239-62. https://doi.org/10.1016/B978-012311632-1/ 50047-4

Hayashi A, Veiga-Santos P, Ditchfield C, Tadini CC. 2006. Investigation of antioxidant activity of cassava starch biobased materials. Proceedings of the $2^{\text {nd }}$ CIGR International Symposium on Future of Food Engineering; Warsaw, Poland; 26-28 April 2006.
Helmut Kaiser Consultancy (HKC). 2016. Bioplastics Market Worldwide 2014-2015-2020-2025 and historical datas 2011-12-13. Available from: http://www.hkc22.com/bioplastics.html. Accessed 2017 January 6.

Huang X, Hsieh F-H. 2005. Physical properties, sensory attributes, and consumer preference of pear fruit leather. J Food Sci 70(3):E177-86. https://doi.org/10.1111/j.1365-2621.2005.tb07133.x.

Jangchud A, Chinnan MS. 1999. Properties of peanut protein film: sorption isotherm and plasticizer effect. LWT-Food Sci Technol 32(2):89-94. https://doi.org/10.1006/fstl.1998.0498.

Jayasekara R, Harding I, Bowater I, Lonergan G. 2005. Biodegradability of a selected range of polymers and polymer blends and standard methods for assessment of biodegradation. J Polym Environ 13(3):231-51. https://doi. org/10.1007/s10924-005-4758-2.

Kaya S, Maskan A. 2003. Water vapor permeability of pestil (a fruit leather) made from boiled grape juice with starch. J Food Eng 57(3):295-9. https:// doi.org/10.1016/S0260-8774(02)00326-6.

Krochta JM, De Mulder-Johnston C. 1997. Edible and biodegradable polymer films: challenges and opportunities. Food Technol. (Chicago, IL, U. S.) 51:61-74.

Krochta JM. 2002. Proteins as raw materials for films and coatings: Definitions, current status, and opportunities. In: Gennadios A, editor. Protein-Based Films and Coatings. Boca Raton, FL:CRC Press. p 1-41. https://doi.org/10.1201/9781420031980.ch1.

Lin D, Zhao Y. 2007. Innovations in the development and application of edible coatings for fresh and minimally processed fruits and vegetables. Compr Rev Food Sci Food Saf 6(3):60-75. https://doi.org/10.1111/j. 1541-4337.2007.00018.x.

Liu B, Zhang J, Liu L, Hotchkiss AT. 2011. Preparation and properties of water and glycerol-plasticized sugar beet pulp plastics. J Polym Environ 19:559-67. https://doi.org/10.1007/s10924-011-0322-4.

Liu F, Avena-Bustillos RJ, Chiou B-S, Li Y, Ma Y, Williams TG, Wood DF, McHugh TH, Zhong F. 2017. Controlled-release of tea polyphenol from gelatin films incorporated with different ratios of free/nanoencapsulated tea polyphenols into fatty food simulants. Food Hydrocolloids 62:212-21. https://doi.org/10.1016/j.foodhyd.2016.08.004.

Lorevice MV, de Moura MR, Aouada FA, Mattoso LHC. 2012

Development of novel guava puree films containing chitosan nanoparticles. J Nanosci Nanotechnol 12(3):2711-7. https://doi.org/10.1166/jnn.2012. $\underline{5716}$

Lorevice MV, de Moura MR, Mattoso LHC. 2014. Nanocomposite of papaya puree and chitosan nanoparticles for application in packaging. Quim Nova 37(6):931-6. https://doi.org/10.5935/0100-4042.20140174.

Lorevice MV, Otoni CG, de Moura MR, Mattoso LHC. 2016. Chitosan nanoparticles on the improvement of thermal, barrier, and mechanical properties of high- and low-methyl pectin films. Food Hydrocolloids 52:732-40. https://doi.org/10.1016/j.foodhyd.2015.08.003.

Mariniello L, Giosafatto CVL, Moschetti G, Aponte M, Masi P, Sorrentino A, Porta R. 2007. Fennel waste-based films suitable for protecting cultivations. Biomacromolecules 8(10):3008-14. https://doi.org/10.1021/ bm0702410

Martelli MR, Barros TT, Assis OBG. 2014. Filmes de polpa de banana produzidos por batelada: Propriedades mecânicas e coloração. Polim Cienc Tecnol 24(1):137-42. https://doi.org/10.4322/polimeros.2014.062.

Martelli MR, Barros TT, Assis OBG. 2015. Produção de filmes plásticos a partir de polpa de frutas sobremaduras. Revista Brasileira de Produtos Agroindustriais 17(3):301-8. doi: 10.15871/1517-8595/rbpa.v17n3p301$\underline{308}$

Martelli MR, Barros TT, de Moura MR, Mattoso LHC, Assis OBG. 2013. Effect of chitosan nanoparticles and pectin content on mechanical properties and water vapor permeability of banana puree films. J Food Sci

78(1):N98-104. https://doi.org/10.1111/j.1750-3841.2012.03006.x.

Martins SIFS, Jongen WMF, van Boekel MAJS. 2000. A review of Maillard reaction in food and implications to kinetic modelling. Trends Food Sci Technol 11(9-10):364-73. https://doi.org/10.1016/S0924-2244(01) 00022-X.

Mattoso LHC, Moreira FKV, Lorevice MV, Otoni CG, de Moura MR, Azeredo HMC, McHugh TH. 2015. Bioplastics made up of fruits puree. $13^{\text {th }}$ Brazilian Meeting on Polymers; Natal, Brazil; 18-22 October 2015. São Carlos, Brazil:Brazilian Polymer Association.

McHugh TH, Avena-Bustillos R, Krochta JM. 1993. Hydrophilic edible films: Modified procedure for water vapor permeability and explanation of thickness effects. J Food Sci 58(4):899-903 https://doi.org/10.1111/j.13652621.1993.tb09387.x 
McHugh TH, de Bord MD, Olsen CW, inventors. 2006. Edible film for wrapping around foods, has specific dry film thickness, moisture content and water activity. U.S. Patent US 2006051464 A1.

McHugh TH, de Bord MD, Olsen CW, inventors. 2012. Edible film, useful in food product, and to wrap around foods to provide a wide range of convenient, nutritious, tasty foods e.g. handheld foods and snack foods, comprises a fruit, vegetable or a combination of fruit and vegetable layer. U.S. Patent US 2012258206 A1.

McHugh TH, Huxsoll CC, Krochta JM. 1996. Permeability properties of fruit puree edible films. J Food Sci 61(1):88-91. https://doi.org/10.1111/j. 1365-2621.1996.tb14732.x

McHugh TH, Olsen CW. 2004. Tensile properties of fruit and vegetable edible films. United States-Japan Cooperative Program in Natural Resources, 104-8.

McHugh TH, Senesi E. 2000. Apple wraps: A novel method to improve the quality and extend the shelf life of fresh-cut apples. J Food Sci 65(3):480-5. https://doi.org/10.1111/j.1365-2621.2000.tb16032.x

Moraes JO, Scheibe AS, Sereno A, Laurindo JB. 2013. Scale-up of the production of cassava starch based films using tape-casting. J Food Eng 119(4):800-8. https://doi.org/10.1016/j.jfoodeng.2013.07.009

Otoni CG, Avena-Bustillos RJ, Chiou B-S, Bilbao-Sainz C, Bechtel PJ, McHugh TH. 2012. Ultraviolet-B radiation induced cross-linking improves physical properties of cold- and warm-water fish gelatin gels and films. J Food Sci 77(9):E215-23. https://doi.org/10.1111/j.1750-3841.2012. 02839.x

Otoni CG, de Moura MR, Aouada FA, Camilloto GP, Cruz RS, Lorevice MV, Soares NFF, Mattoso LHC. 2014. Antimicrobial and physical-mechanical properties of pectin/papaya puree/cinnamaldehyde nanoemulsion edible composite films. Food Hydrocolloids 41:188-94. https://doi.org/10.1016/j.foodhyd.2014.04.013.

Otoni CG, Espitia PJP, Avena-Bustillos RJ, McHugh TH. 2016. Trends in antimicrobial food packaging systems: emitting sachets and absorbent pads. Food Res Int 83:60-73. https://doi.org/10.1016/j.foodres.2016.02.018.

Otoni CG, Lorevice MV, de Moura MR, Corrêa DS, Mattoso LHC. 2015. Efeito plastificante de polpa de pêssego em bioplásticos comestíveis. $13^{\text {th }}$ Brazilian Meeting on Polymers; Natal, Brazil; 18-22 October 2015. São Carlos, Brazil:Brazilian Polymer Association.

Park S-i, Zhao Y. 2006. Development and characterization of edible films from cranberry pomace extracts. J Food Sci 71(2):E95-101. https://doi.org/ 10.1111/j.1365-2621.2006.tb08902.x.

Peretto G, Du W-X, Avena-Bustillos RJ, Sarreal SBL, Hua SST, Sambo P, McHugh TH. 2014. Increasing strawberry shelf-life with carvacrol and methyl cinnamate antimicrobial vapors released from edible films. Postharvest Biol Technol 89:11-8. https://doi.org/10.1016/j.postharvbio. 2013.11.003.

Petersson L, Oksman K. 2006. Biopolymer based nanocomposites: comparing layered silicates and microcrystalline cellulose as nanoreinforcement. Compos Sci Technol. 66(13):2187-96. https://doi.org/ 10.1016/j.compscitech.2005.12.010.

Porta R, Mariniello L, Di Pierro P, Sorrentino A, Giosafatto CVL. 2011. Transglutaminase crosslinked pectin- and chitosan-based edible films: a Review. Crit Rev Food Sci Nutr 51:223-238. https://doi.org/10.1080/ 10408390903548891

Ravishankar S, Jaroni D, Zhu L, Olsen C, McHugh T, Friedman M. 2012. Inactivation of Listeria monocytogenes on ham and bologna using pectin-based apple, carrot, and hibiscus edible films containing carvacrol and cinnamaldehyde. J Food Sci 77(7):M377-82. https://doi.org/10.1111/j. 1750-3841.2012.02751.x.

Ravishankar S, Zhu L, Olsen CW, McHugh TH, Friedman M. 2009. Edible apple film wraps containing plant antimicrobials inactivate foodborne pathogens on meat and poultry products. J Food Sci 74(8):M440-5. https:// doi.org/10.1111/j.1750-3841.2009.01320.x.

Reis LCB, Souza CO, da Silva JBA, Martins AC, Nunes IL, Druzian JI. 2015. Active biocomposites of cassava starch: the effect of yerba mate extract and mango pulp as antioxidant additives on the properties and the stability of a packaged product. Food Bioprod Process 94:382-91. https://doi.org/10. 1016/j.fbp.2014.05.004.

Rojas-Graü MA, Avena-Bustillos RJ, Friedman M, Henika PR, Martín-Belloso O, McHugh TH. 2006. Mechanical, barrier, and antimicrobial properties of apple puree edible films containing plant essential oils. J Agric Food Chem 54(24):9262-7. https://doi.org/10.1021/ je061717u.

Rojas-Graü MA, Avena-Bustillos RJ, Olsen C, Friedman M, Henika PR, Martín-Belloso O, Pan Z, McHugh TH. 2007. Effects of plant essential oils and oil compounds on mechanical, barrier and antimicrobial properties of alginate-apple puree edible films. J Food Eng 81(3):634-41. https://doi. org/10.1016/j.jfoodeng.2007.01.007.

Rossman JM. 2009. Commercial manufacture of edible films. In: Huber CK, Embuscado EM, editors. Edible films and coatings for food applications. New York, NY: Springer New York. p 367-90. https://doi.org/10.1007/ 978-0-387-92824-1_14.

Rouilly A, Geneau-Sbartai C, Rigal L. 2009. Thermo-mechanical processing of sugar beet pulp. III. Study of extruded films improvement with various plasticizers and cross-linkers. Bioresour Technol 100(12):3076-81. https:// doi.org/10.1016/j.biortech.2008.12.047.

Shen Z, Ghasemlou M, Kamdem DP. 2015. Development and compatibility assessment of new composite film based on sugar beet pulp and polyvinyl alcohol intended for packaging applications. J Appl Polym Sci 132(4):41354 https://doi.org/10.1002/app.41354.

Shin S-H, Kim S-J, Lee S-H, Park K-M, Han J. 2014. Apple peel and carboxymethylcellulose-based nanocomposite films containing different nanoclays. J Food Sci 79(3):E342-53. https://doi.org/10.1111/1750-3841. 12356.

Silva JBA, Pereira FV, Druzian JI. 2012. Cassava starch-based films plasticized with sucrose and inverted sugar and reinforced with cellulose nanocrystals. J Food Sci 77(6):N14-9. https://doi.org/10.1111/j.1750-3841.2012. 02710.x.

Sothornvit R, Krochta JM. 2005. Plasticizers in edible films and coatings. In: Han JH, editor. Innovations in Food Packaging. London, United Kingdom: Academic Press. p 403-33. https://doi.org/10.1016/B978-012311632-1/ 50055-3.

Sothornvit R, Pitak N. 2007. Oxygen permeability and mechanical properties of banana films. Food Res Int 40(3):365-70. https://doi.org/10. 1016/j.foodres.2006.10.010.

Sothornvit R, Rodsamran P. 2008. Effect of a mango film on quality of whole and minimally processed mangoes. Postharvest Biol Technol 47(3):407-15. https://doi.org/10.1016/j.postharvbio.2007. $\underline{08.005}$

Sothornvit R, Rodsamran P. 2010a. Fresh-cut mango coated with mango film in modified atmosphere packaging. Acta Hortic 857:359-66. https:// doi.org/10.17660/ActaHortic.2010.857.43.

Sothornvit R, Rodsamran P. 2010b. Mango film coated for fresh-cut mango in modified atmosphere packaging. Int J Food Sci Technol 45(8):1689-95. https://doi.org/10.1111/j.1365-2621.2010.02316.x.

Souza CO, Silva LT, Druzian JI. 2012. Comparative studies on the characterization of biodegradable cassava starch films containing mango and acerola pulps. Quim Nova 35(2):262-7. https://doi.org/10.1590/S010040422012000200006.

Souza CO, Silva LT, Silva JR, López JA, Veiga-Santos P, Druzian JI. 2011. Mango and acerola pulps as antioxidant additives in cassava starch bio-based film. J Agric Food Chem 59(6):2248-54. https://doi.org/10.1021/ jf1040405.

Tulamandi S, Rangarajan V, Rizvi SSH, Singhal RS, Chattopadhyay SK, Saha NC. 2016. A biodegradable and edible packaging film based on papaya puree, gelatin, and defatted soy protein. Food Packag Shelf Life 10:60-71.

United States Environmental Protection Agency (EPA). 2016. Municipal solid waste generation, recycling, and disposal in the United States: facts and figures for 2012. Available from: https://www.epa.gov/sites/production/ files/2015-09/documents/2012_msw_fs.pdf. Accessed 2017 January 6.

Valdes A, Mellinas AC, Ramos M, Burgos N, Jimenez A, Garrigos MC. 2015. Use of herbs, spices and their bioactive compounds in active food packaging. RSC Adv 5:40324-35. https://doi.org/10.1039/C4RA17286H Valenzuela C, Aguilera JM. 2015. Effects of different factors on stickiness of apple leathers. J Food Eng 149:51-60. https://doi.org/10.1016/ j.jfoodeng.2014.09.029.

Veiga-Santos P, Oliveira LM, Cereda MP, Scamparini ARP. 2007. Sucrose and inverted sugar as plasticizer. Effect on cassava starch-gelatin film mechanical properties, hydrophilicity and water activity. Food Chem 103(2):255-62. https://doi.org/10.1016/j.foodchem.2006. $\underline{07.048 .}$

Xu Y, Scales A, Jordan K, Kim C, Sismour E. 2017. Starch nanocomposite films incorporating grape pomace extract and cellulose nanocrystal. J Appl Polym Sci 134(6):44438. https://doi.org/10.1002/app.44438.

Wang A, Wu L, Wang X, Zhu J, inventors. 2012a. Method for preparing edible wrapping paper by taking celeries as raw materials. Chinese Patent CN 102071599 B. 
Wang A, Wu L, Wang X, Zhu J, inventors. 2012b. Method for preparing edible wrapping paper by taking corn-peel dietary fibers as raw materials. Chinese Patent CN 102071595 B.

Wang A, Wu L, Wang X, Zhu J, inventors. 2012c. Production method of edible packing paper taking corn peels as raw materials. Chinese Patent CN 102071594 B.

Wang A, Wu L, Wang X, Zhu J, inventors. 2012d. Method for preparing edible, preservative and antibacterial paper. Chinese Patent CN 102071591 B.

Wang A, Wu L, Wang X, Zhu J, inventors. 2012e. Method for preparing edible wrapping paper by taking Dangshan pears as raw materials. Chinese Patent CN 102071600 B.

Wang X, Liu H, Wei J, Ma Z. 2011a. Effects of oregano oil, carvacrol, cinnamaldehyde, and citral on antimicrobial, mechanical and barrier properties of carrot puree films. Proceedings SPIE 7752, PIAGENG 2010
Photonics and Imaging for Agricultural Engineering, 77521D; Qingdao, China; 04 February 2011. https://doi.org/10.1117/12.886665.

Wang X, Sun X, Liu H, Li M, Ma Z. 2011b. Barrier and mechanical properties of carrot puree films. Food Bioprod Process 89(2):149-56. https://doi.org/10.1016/j.fbp.2010.03.012.

Yoruk R, Marshall MR. 2003. Physicochemical properties and function of plant polyphenol oxidase: a review. J Food Biochem 27(5):361-422. https:// doi.org/10.1111/j.1745-4514.2003.tb00289.x.

Zhu L, Olsen C, McHugh T, Friedman M, Jaroni D, Ravishankar S. 2014. Apple, carrot, and hibiscus edible films containing the plant antimicrobials carvacrol and cinnamaldehyde inactivate Salmonella Newport on organic leafy greens in sealed plastic bags. J Food Sci 79(1):M61-6. https://doi.org/ 10.1111/1750-3841.12318. 